\title{
MINERAL INDUSTRY OF ALASKA IN 1926
}

\author{
By Philip S. Smith ${ }^{1}$
}

\section{INTRODUCTION}

Records of what has been done in an industry are of service not only as matters of history but also as means of gaging the probable future developments in that industry. The investigations of the mineral resources of Alaska which the Geological Survey has been carrying on now for more than a quarter of a century have therefore included annually the collection of data regarding the production of the different ores and minerals, which up to the end of 1926 have yielded more than half a billion dollars. A preliminary statement of the production is published immediately at the end of each calendar year, but many of the figures included in that statement must be estimated, as the detailed facts are not then available. Subsequently these estimates are revised in the light of more complete data, and the results are made available in more accurate and detailed form in a series of publications, of which this one for 1926 is the twenty-third. ${ }^{2}$

The data for these annual surveys of the mineral industry come from a number of sources. The field men of the Geological Survey engaged in Alaskan surveys acquire at first hand much information regarding the mineral industry in the region in which they work or in the course of their travel to and from the field. Other Government services-as, for instance, the Bureau of Mines, the Bureau of the Mint, and the Customs Service-in the course of their regular duties also collect many data that are pertinent to these studies and ean be used, thus avoiding unnecessary duplication. Many of the banks, express companies, and other business organizations and individuals also obtain for their own use much information that bears on the general problem and can be disclosed to the Geological Survey without violating confidence. A great deal of this information is

1 The statistics' in this chapter have been compiled largely by Miss IE. C. Nichols and Miss E. W. McKeige.

2 The other volumes of this series, commencing with that for 1904, are U. S. Geol. Survey Bull. 259, 284, 314, 345, 379, 442, 480, 520, 542, 592, 622, 642, 662, 692, 712, 714, $722,739,755,773,783$, and 792 . 
generously put at the disposal of the Geological Survey and either used directly or as a check against data obtained from other sources. Many of the important Alaska newspapers are courteously sent to the Geological Survey, and from them and the technical press are gleaned valuable notes on new developments.

In addition to all these sources the Geological Survey each year sends to each person known to be operating a mine or prospect schedules on which are queries to be answered regarding work on the individual property during the year. These schedules should furnish the most authoritative data regarding the mining developments. It is, extremely gratifying and an evidence of the general appreciation in which these annual summaries are held that although the return of the schedules and the giving of information are entirely voluntary, a great many of the operators cooperate fully and cordially with the Geological Survey by furnishing the desired data.

Unfortunately, however, some of the schedules are not completely answered, others are not returned at all, and some are returned so late that in order not to delay the report unduly the books have been closed before they are received and the data have had to be taken from some less authoritative source. In the interest of making these annual statements more exact and therefore more useful to the mining industry as a whole, each operator is urged to complete his schedule accurately and to forward it to the Geological Survey at as early a date as practicable. Many operators who have only produced a small amount doubtless feel that their mite is so insignificant that it is not worth reporting. It should be remembered, however, that even a few hundred dollars taken out by each of a number of prospectors becomes a truly respectable sum in the aggregate. Furthermore, definite information that only a small amount was produced from a certain claim may prevent making. an erroneous overestimate based on information from less authoritative sources. It is probably hardly necessary to state that all the information furnished on these schedules is regarded as confidential and is not used by the Government in any way that will be disadvantageous to the individual concerned. The data are compiled in such a manner that the production of individual operators or companies is not disclosed unless the explicit permission of the responsible individual has been obtained or unless the companies themselves publish their production in annual reports which are issued to their stockholders and other interested individuals. So scrupulously is the practice adhered to, of holding the returns recorded on the schedules confidential, that frequently it has been necessary to group certain minerals or districts in an artificial manner in order that the production of individuals may not be shown. This is the reason, 
for instance, that marble, petroleum, and a number of other products are lumped together in certain tables as a group of miscellaneous mineral products, and that the production of certain districts is included with that from another district. Although this grouping has not been entirely natural or, in certain instances, even logical and has often obscured significant facts, it has been considered the best means of keeping faith with those whose individual production would otherwise have been revealed.

\section{ACKNOWLEDGMENTS}

From the foregoing short description of the way in which the data have been obtained for the accompanying report, it is evident that a great many persons have contributed information essential for its preparation. The list of contributors would include most of the mining men of the Territory and scores of others. The list, in fact, is so long that it is impracticable to distinguish by name all who may be regarded as collaborators in this work. A number, however, have given special assistance, and individual mention of these is gratefully given.

Special acknowledgment is due to the directors and other officers of the Bureau of Mines and Bureau of the Mint; the collector and other officers of the Alaska customs service; the officers of the Alaska Railroad; F. H. Moffit, S. R. Capps, J. B. Mertie, jr., B. D. Stewart, and N. L. Wimmler, of the Geological Survey; Volney Richmond, of the Northern Commercial Co.; John C. McBride and the Alaska Juneau Gold Mining Co., of Juneau; E. H. Bartholf, of Hyder; the Hirst-Chichagof Mining Co. and Chichagoff Development Co., of Chichagof; the Kennecott Copper Corporation, of Kennecott; Thomas Larson, of Kotsina; M. J. Knowles, of Valdez; S. W. Jensen and H. W. Nagley, of Talkeetna; Alex Liska, of Anehorage; J. H. Lander, of Wasilla; N. E. Bolshanin, of Unalaska; Arthur Moose Johnson, of Chulitna; Charles Zielke, of Nenana; J. J. Hillard, of Eagle; Frank Montgomery, of Steel Creek; O. A. McConnell, of Chatanika; A. W. Amero, of Beaver; James H. Morris, of Jack Wade; Henry Cook, the First National Bank, Fairbanks Exploration Co., G. E. Jennings, and Lynn Smith, of Fairbanks; the Miners and Merchants Bank, of Iditarod; E. J. Stier, of Flat; William Schneirla and Frank Speljack, of Ophir; H. W. Reeth, of Akiak; Alex Mitchell, of Kantishna; W. D. English, of Bettles; E. J. Ulen, of Wiseman; Tom Plunkett, of Fortuna Ledge; Rev. John W. Chapman, of Anvik; William Yanert, of Purgatory; A. J. Griffin, of Richardson; J. R. Murphy, of the Kuskokwim Dredging Co., McGrath; John Haroldson, A. Stecker, and J. L. Jean, of Quinhagak; the Hammon Consolidated Gold Fields, the Miners \& Mer- 
chants Bank, J. J. O'Leary, S. M. Gaylord, and R. W. J. Reed, of Nome; E. M. Marx, of Teller; A. V. Cordovado, of Deering; A. S. Tucker and John Bahnke, of Bluff; E. J. Mathews, T. P. Roust, and the Keewalik Mining Co., of Candle; Wallace L. Johnson, of Council; Lewis Lloyd and James C. Cross, of Shungnak; Clarence H. Hawkins, of Kiana; and Arthur W. Johnson, of Haycock.

\section{MINERAL PRODUCTION}

Success is so often gaged by mere increase that the bald statement that the mineral production of Alaska in 1926 was somewhat less than in 1925 may be taken by some as marking a retrogression in the mining industry. Such is not the case, however, because many of the conditions that explain the decrease are of themselves such as to presage increased production in the future. For instance, in many districts the gathering together and consolidation of a large number of claims formerly operated separately, the careful working out of comprehensive methods of economically mining the ground, the acquisition of suitable machinery and equipment, and the undertaking of large engineering feats, while perhaps temporarily suspending some desultory productive work, clearly portend more productive work in the near future, and these are the conditions that are prevailing in many of the camps throughout the Territory. It is true that mining is no longer the principal productive business in Alaska, but an annual production of copper, gold, silver, lead, and other minerals to the value of more than $\$ 17,000,000$ still entitles mining to second place and makes it an exceedingly important industry. In fact, the significance of this production becomes even more impressive when the relatively small number of persons engaged in mining in the Territory is considered. It has become more or less the custom of many people in considering Alaskan matters to analyze the problems on the false basis of relation to total population instead of to area, or cost, or some other proper basis. Mining production, however, can properly be examined on the basis of numbers engaged in mining or related enterprises. When analyzed in this way it is seen that the ratio between the value of the mineral production of the Territory and its estimated total population is at least ten times the similar ratio for the rest of the United States. In other words, the average Alaskan resident is much more vitally concerned with the new wealth coming from that country's mineral resources than the average resident of the rest of the country.

Even the reported decrease in the value of the mineral production can not be properly attributed entirely to decreased mining activity, because the prices paid for many of the mineral products were lower in 1926 than in 1925. For instance, the average price of silver, as 
computed by the Bureau of Mines, was about 7 cents less an ounce than in 1925, and according to the same authority copper was about two-tenths of a cent a pound less. The prices of coal, lead, and palladium were also lower in 1926 than in 1925. A considerable falling off in the total value of the Alaskan mineral production would therefore have been inevitable under these conditions even if the production had remained constant or increased slightly. It is obvious, however, that a period of low prices is not a time to stimulate production, so that under such conditions it might reasonably be expected that a wise manager would reduce the output of his mine so far as outstanding contracts, fixed charges, and other conditions would permit.

Viewed broadly, therefore, the mining industry of the Territory as a whole seems to be in a distinctly encouraging condition. Many new enterprises are under way that should begin to yield results soon, though some of the plans that are being actively prosecuted will not be completed for several years. Most of the new work is being handled efficiently, and foresight in planning is the present keynote rather than the former one of untrammeled optimism checked only by regretful hindsight. In many plants old and obsolete equipment is being discarded and new, efficient machinery installed. Careful and extensive experimentation is being done at many places to determine essential. factors. These experiments cover a range from ore-dressing problems to methods of thawing frozen ground economically. Skilled engineers are being increasingly employed to solve mining and milling problems and are beginning to convince even the old-style prospector and operator that mining is a skilled profession in which technical training is infinitely more effective than even the most energetic and willing operator without that skill.

Value of total mineral production of Alaska, 1880-1926

\begin{tabular}{|c|c|c|c|}
\hline \multicolumn{2}{|c|}{ By years } & \multicolumn{2}{|l|}{ By substances } \\
\hline 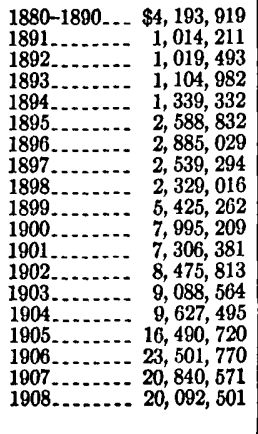 & 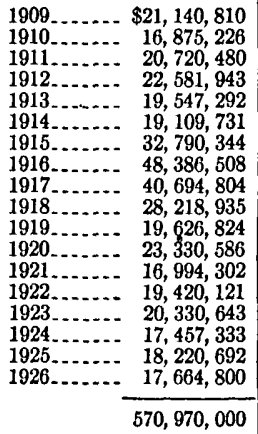 & $\begin{array}{l}\text { Gold } \\
\text { Copper } \\
\text { Silver } \\
\text { Coal } \\
\text { Tin } \\
\begin{array}{l}\text { Lend } \\
\text { Antimony } \\
\text { Marble and other products (including } \\
\text { platinum metals) }\end{array}\end{array}$ & $\begin{array}{r}\$ 360,308,000 \\
187,663,000 \\
10,864,000 \\
5,004,000 \\
973,000 \\
1,195,000 \\
238,000 \\
4,725,000 \\
570,970,000\end{array}$ \\
\hline
\end{tabular}


As can be seen from the accompanying table, the value of the mineral production of Alaska in 1926 was $\$ 17,664,800$. The total since 1880, when mining may be considered as having commenced in the Territory, exceeds $\$ 570,000,000$. By far the greater part of this amount has been in gold and copper, which together formed about 96 per cent of the total value, or 63 and 33 per cent, respectively. The proportion of the value of gold to the total production is gradually changing, so that in 1926 only 92 per cent of the total was in copper and gold, and the relation between these two was such that copper formed about 54 per cent and gold 38 per cent. The decreasing proportion that these metals bear to the total mineral production is indicative of the broadening out of the mining industry and shows that already many different minerals are a source of wealth to the Territory. Many of the minerals that are now produced only in small quantities are certain to be mined more extensively as transportation facilities increase, so that the more bulky commodities can be carried economically to centers for treatment or distributed more broadly for use.

Mineral output of Alaska, 1925 and 1926

\begin{tabular}{|c|c|c|c|c|c|c|}
\hline & \multicolumn{2}{|c|}{1925} & \multicolumn{2}{|c|}{1926} & \multicolumn{2}{|c|}{1926 (increase or decrease) } \\
\hline & Quantity & Value & Quantity & Value & Quantity & Value \\
\hline \multirow{3}{*}{ 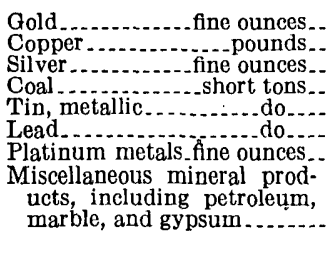 } & $\begin{array}{r}307,679 \\
73,855,298 \\
698,259 \\
82,868 \\
13.8 \\
789\end{array}$ & \multirow[t]{2}{*}{$\begin{array}{r}\$ 6,360,281 \\
10,361,336 \\
482,495 \\
404,617 \\
15,980 \\
140,571 \\
(a)\end{array}$} & \multirow[t]{2}{*}{$\begin{array}{r}324,450 \\
67,778,000 \\
690,000 \\
87,300 \\
8 \\
778 \\
3,570\end{array}$} & \multirow[t]{2}{*}{$\begin{array}{r}\$ 6,707,000 \\
9,489,000 \\
430,500 \\
459,000 \\
10,400 \\
124,400 \\
274,500\end{array}$} & $\begin{array}{r}+16,771 \\
-6,077,298 \\
-8,259 \\
+4,432 \\
-5.8 \\
-11\end{array}$ & \multirow{2}{*}{$\begin{array}{r}+\$ 346,719 \\
-872,336 \\
-51,995 \\
+54,383 \\
-5,580 \\
-16,171 \\
(a) \\
\\
-285,414\end{array}$} \\
\hline & & & & & & \\
\hline & & $18,220,692$ & & $17,664,800$ & & $-555,892$ \\
\hline
\end{tabular}

- Platinum for 1925 included in "Miscellaneous mineral products."

In this table, for the sake of comparison, the amounts of similar products mined in 1925 are given in parallel columns and the relative increase or decrease in 1926 indicated. Each of the main metals and nonmetallic minerals produced is described in some detail in the succeeding pages, but certain general features may be pointed out here. The most notable increases are shown in both the quantity and value of the gold produced, but there was some increase also in the quantity and value of the coal mined and sold. The production of lead in the two years showed practically no change, but the decrease in value, owing to the general lower market price that prevailed in 1926, caused the total value of lead produced to be much lower. There was considerable decrease in both the quantity and the value of the copper produced and some decrease in the quantity 
and value of silver, tin, lead, and platinum. Most of the mineral products grouped under the heading "Miscellaneous mineral products" show no notable change from the preceding year.

The reason for some of the changes in rate of production are discussed under the individual minerals, but it may be pointed out here that the decrease of production of one metal may involve decrease in another one as well. For instance, decrease in the production of Alaskan copper naturally results in a decrease in the silver production, for the largest part of the silver comes from the copper ores, though in those ores the silver of itself has so little value that the ore could not be worked for its silver content alone.

\section{GOLD}

\section{TOTAL PRODUCTION}

The total value of the gold produced in Alaska in 1926 amounted to $\$ 6,707,000$, which was about $\$ 350,000$ more than was produced in 1925. The following table gives a record of the production of gold from the Territory from the earliest days and shows that for the past four years the annual production has been steadily increasing. Before that time for seven years there was a more or less uniform decrease, owing to the decline in bonanza mining.

Gold and silver produced in Alaska, 1880-1926

\begin{tabular}{|c|c|c|c|c|c|c|}
\hline \multirow{2}{*}{ Year } & \multicolumn{2}{|c|}{ Gold } & \multicolumn{2}{|c|}{ Silver } & \multicolumn{2}{|c|}{ Value of gold by sources } \\
\hline & Fine ounces & Value & Fine ounces & Value & Placer mines & Lode mines \\
\hline \multirow[t]{2}{*}{$\begin{array}{l}1880-1915 \\
1916 \\
1917 \\
1918 \\
1919 \\
1920 \\
1922 \\
1923 \\
1924 \\
1925\end{array}$} & $\begin{array}{r}12,592,121 \\
834,068 \\
709,049 \\
458,641 \\
455,984 \\
404,683 \\
390,558 \\
359,057 \\
289,539 \\
304,072 \\
307,679 \\
324,450\end{array}$ & $\begin{array}{r}\$ 260,302,243 \\
17,241,713 \\
14,657,353 \\
9,480,952 \\
9,426,032 \\
8,365,560 \\
8,073,540 \\
7,422,367 \\
5,985,314 \\
6,285,724 \\
6,360,281 \\
6,707,000\end{array}$ & $\begin{array}{r}4,923,198 \\
1,379,171 \\
1,239,150 \\
847,789 \\
629,708 \\
953,546 \\
761,085 \\
729,945 \\
814,649 \\
669,641 \\
698,259 \\
690,000\end{array}$ & $\begin{array}{r}\$ 2,821,911 \\
907,495 \\
1,021,060 \\
847,789 \\
705,708 \\
1,039,364 \\
761,085 \\
729,945 \\
668,012 \\
448,659 \\
482,495 \\
430,500\end{array}$ & $\begin{array}{r}185,200,444 \\
11,140,000 \\
9,810,000 \\
5,900,000 \\
4,970,000 \\
3,873,000 \\
4,226,000 \\
4,395,000 \\
3,608,500 \\
3,564,000 \\
3,223,000 \\
3,769,000\end{array}$ & $\begin{array}{r}75,101,799 \\
6,101,713 \\
4,847,353 \\
3,580,952 \\
4,456,032 \\
4,492,560 \\
3,847,540 \\
3,027,367 \\
2 ; 376,814 \\
2,721,724 \\
3,137,281 \\
2,938,000\end{array}$ \\
\hline & $17,430,900$ & $360,308,000$ & $14,336.200$ & $10,864,000$ & $243,679,000$ & $116,629,200$ \\
\hline
\end{tabular}

The gold produced came from mines that may be grouped into two main types-placers and lodes. The placers are those sand and gravel deposits most of whose material has been worn from the hard rocks in the general vicinity and in which gold or other minerals of value have been more or less concentrated by surficial geologic. processes acting on some physical property peculiar to the material thus concentrated. The lodes are the mineralized veins or masses in the country rock formed in general through deep-seated geologic processes and represent the material in place. Lodes contain differ- 
ent valuable minerals and may be designated by the name of their most valuable constituent, as gold lodes, copper lodes, or silver lodes.

Gold is so common in lodes containing metallic minerals that from traces to large amounts are found in almost all such lodes. It is not always evident which is the most valuable mineral in an ore, for the value may be determined by its total mineral content, and many mines would not be profitable to work except for their combined content of gold, silver, lead, and perhaps copper. In the following table all the ores that are valuable principally for their copper or leadsilver content are separated from the other ores from lode mines and listed as copper and lead ores, and the others are recorded as gold ores. In the group of ores that are distinctly most valuable for their copper or silver content are included the ores in which the principal value is in the platinum metals, though they carry a considerable additional value in copper and a lesser amount in gold. It will be noted that only a little gold is reported from the group of copper and lead ores. In fact, it is noteworthy that practically the bulk of the Alaskan copper is devoid of any appreciable quantity of gold. Under the heading "placer" is included all the gold won by placer mining of any type. The ratio between the gold produced from all the lodes and that produced from placers in 1926 was about 44 to 56 , and the ratio between the gold from lodes classified as distinctly gold lodes and that from the placers is practically the same.

Gold and silver produced in Alaska, 1926, by sources

\begin{tabular}{|c|c|c|c|c|}
\hline \multirow{2}{*}{ Source } & \multicolumn{2}{|c|}{ Gold } & \multicolumn{2}{|c|}{ Silver } \\
\hline & Fine ounces & Value & Fine ounces & Value \\
\hline \multirow[t]{2}{*}{$\begin{array}{l}\text { Gold ores }(3,924,925 \text { tons }) \\
\text { Copper and lead ores }(670,427 \text { tons) } \\
\text { Placers }\end{array}$} & $\begin{array}{r}140,190 \\
1,935 \\
182,325\end{array}$ & $\begin{array}{r}\$ 2,898,000 \\
40,000 \\
3,769,000\end{array}$ & $\begin{array}{r}59,940 \\
605,190 \\
24,870\end{array}$ & $\begin{array}{r}\$ 37,400 \\
377,600 \\
15,500\end{array}$ \\
\hline & 324,450 & $6,707,000$ & 690,000 & $430,50 d$ \\
\hline
\end{tabular}

GOLD LODES

Somewhat less than half of the gold produced in Alaska in 1926) came from lode deposits. These were widely distributed throughout the Territory, but, according to the practice of the Geological Survey, lode properties that produced less than $\$ 1,000$ in gold are considered merely prospects, and only those that produced more than that have been counted as mines. According to this definition there were 24| gold mines in operation in 1926. These were distributed as shown in the accompanying table, which also gives other data regarding the production of these districts. 
Gold and silver produced from gold-lode mines in Alaska in 1926, by districts

\begin{tabular}{|c|c|c|c|c|c|c|}
\hline \multirow{2}{*}{ District } & \multirow{2}{*}{$\begin{array}{l}\text { Num- } \\
\text { ber. of } \\
\text { mines }\end{array}$} & \multirow{2}{*}{$\begin{array}{c}\text { Ore mined } \\
\text { (short tons) }\end{array}$} & \multicolumn{2}{|c|}{ Gold } & \multicolumn{2}{|c|}{ Silver } \\
\hline & & & $\begin{array}{c}\text { Fine } \\
\text { ounces }\end{array}$ & Value & $\begin{array}{c}\text { Fine } \\
\text { ounces }\end{array}$ & Value \\
\hline $\begin{array}{l}\text { Southeastern Alaska } \\
\text { Willow Creek } \\
\text { Fairbanks district............. } \\
\text { Other districts. }\end{array}$ & $\begin{array}{l}7 \\
5 \\
5 \\
7\end{array}$ & $\begin{array}{r}3,866,925 \\
50,000 \\
4,500 \\
3,500\end{array}$ & $\begin{array}{r}120,115 \\
16,157 \\
2,467 \\
1,451\end{array}$ & $\begin{array}{r}\$ 2,483,000 \\
334,000 \\
51,000 \\
30,000\end{array}$ & $\begin{array}{r}57,690 \\
1,270 \\
590 \\
390\end{array}$ & $\begin{array}{r}\$ 36,000 \\
790 \\
370 \\
240\end{array}$ \\
\hline & 24 & $3,924,925$ & 140,190 & $2,898,000$ & 59,040 & 37,400 \\
\hline
\end{tabular}

By far the greater part of the lode production-about 85 per cent-came from gold lodes in southeastern Alaska. The outstanding mine in this region is operated by the Alaska Juneau Gold Mining Co. The magnitude of the mining operations of this company is shown by the statements contained in its annual report, ${ }^{3}$ from which the following facts are abstracted:

The total rock mined and trammed to the mill in 1926 was $3,829,700$ tons, or an average of practically 10,500 tons for each of the 365 days of the year. Of this amount $1,649,678$ tons were milled, the rest being rejected. The average assay value of all the material mined was 75 cents a ton. The amount of gold in the part rejected was about 20 cents a ton, and the value of the mineral content of the material which was further treated was $\$ 1.47$. Of this value about 30 cents a ton was lost in treatment, 91 cents recovered as bullion, and 26 cents recovered in galena and other concentrates which are later smelted. The following table compiled from the report cited gives the significant data regarding the production of this mine in 1926 and affords a comparison with that of earlier years:

Production of Alaska Juneau mine, 1893-1926

\begin{tabular}{|c|c|c|c|c|c|c|c|}
\hline \multirow[b]{2}{*}{ Year } & \multicolumn{3}{|c|}{ Ore (tons) } & \multicolumn{4}{|c|}{ Metals recovered } \\
\hline & Total & $\begin{array}{c}\text { Fine } \\
\text { milled }\end{array}$ & $\begin{array}{l}\text { Coarse } \\
\text { tailings } \\
\text { rejected }\end{array}$ & Gold & $\begin{array}{c}\text { Silver } \\
\text { (ounces) }\end{array}$ & $\begin{array}{c}\text { Lead } \\
\text { (pounds) }\end{array}$ & Total value \\
\hline $\begin{array}{l}1893-1913 \\
1914-1915 \\
1916 \\
1917 \\
1918 \\
1919 \\
1920 \\
1921 \\
1922 \\
1923 \\
1924 \\
1925 \\
1926\end{array}$ & $\begin{array}{r}507,254 \\
242,328 \\
180,113 \\
677,410 \\
592,218 \\
692,895 \\
942,870 \\
1,613,600 \\
2,310,550 \\
2,476,240 \\
3,068,190 \\
3,481,780 \\
3,829,700 \\
\end{array}$ & $\begin{array}{r}330,278 \\
239,918 \\
180,113 \\
677,410 \\
574,285 \\
616,302 \\
637,321 \\
904,323 \\
1,108,559 \\
1,134,759 \\
1,367,528 \\
1,537,884 \\
1,649,678\end{array}$ & \begin{tabular}{r}
176,976 \\
2,410 \\
\hdashline 17,933 \\
76,593 \\
305,549 \\
709,277 \\
$1,201,991$ \\
$1,341,481$ \\
$1,700,662$ \\
$1,943,896$ \\
$2,180,022$
\end{tabular} & $\begin{array}{r}\$ 707,730 \\
251,655 \\
115,022 \\
429,262 \\
430,124 \\
499,002 \\
732,870 \\
969,703 \\
1,296,157 \\
1,427,199 \\
1,907,374 \\
2,030,067 \\
1,931,052\end{array}$ & $\begin{array}{r}\text { Lost in } \\
6,192 \\
2,844 \\
12,248 \\
11,828 \\
16,431 \\
23,348 \\
40,619 \\
49,404 \\
41,876 \\
63,191 \\
55,971 \\
51,004\end{array}$ & \begin{tabular}{|r|} 
tailing. \\
117,031 \\
61,068 \\
296,179 \\
273,297 \\
359,762 \\
487,574 \\
550,913 \\
687,315 \\
755,423 \\
$1,256,857$ \\
$1,288,974$ \\
$1,300,915$
\end{tabular} & $\begin{array}{r}\$ 707,730 \\
261,326 \\
121,370 \\
460,666 \\
459,445 \\
542,714 \\
791,300 \\
1,035,251 \\
1,388,679 \\
1,514,774 \\
2,055,782 \\
2,184,384 \\
2,067,836\end{array}$ \\
\hline & $20,615,148$ & $10,958,358$ & $9,666,790$ & $12,727,217$ & 374,956 & $7,435,308$ & $12,591,350$ \\
\hline
\end{tabular}

'Alaska Juneau Gold Mining Co. Twelfth Ann. Rept., for 1926, 14 pp., 1927. 
Among the other items of note contained in this company's report is the statement that alterations and additions that had been in progress at the milling plant for some time were completed during the year, so that the capacity of the plant is now 14,000 tons of ore a day. This is 3,000 to 4,000 tons a day more than it handled in January, 1926. Additional prospecting underground and experimentation in bettering milling practice are to be undertaken. Although it is realized that these improvements will probably somewhat increase the cost per ton for mining and milling, it is believed that the increase will be more than offset by increased recovery of metals.

The next most productive gold mines in southeastern Alaska are all near the northwest coast of Chichagof Island and are operated by the Chichagoff Development Co., Apex-El Nido Mining Co., and Hirst-Chichagof Mining Co. Productive mining was carried on at all these mines, though the Apex-El Nido property, which was idle in 1925 , did not get under way until early in June. At each of these mines there is a constant tendency to increase the ore reserves by handling lower-grade ore. This has resulted in constantly increasing the demand for power. It is understood that plans were on foot at the Hirst-Chichagof mine to install a new Diesel engine during the late fall and winter, so as to be in condition to handle a considerably larger tonnage in the season of 1927. In this same general region there are a number of properties on which signs of mineralization have been found and on some of which prospecting is under way. One of the companies, formerly the Pinta Bay Mining Co., was reorganized during the year as the West Coast Development Co. and, if its plans carry through, expects to be actively exploring its ground in the near future.

Gold is contained in some of the ores in the Hyder district, but at 1 the operating mines it is subordinate in value to the silver and lead. In the vicinity of Ketchikan a little work has been done on a number of small prospects that have been known for many years, but none are known to have produced more than a few hundred dollars in gold during the year except the palladium mine of the Alaska Palladium Co. on Prince of Wales Island. The ore of this mine, as the name indicates, is valuable principally for the platinum metals, though it carries also considerable copper and a little gold. This mine is noted in more detail in a later section of this report. At the Kassan Gold Co.'s mine near Hollis, which was formerly the Julia or Dunton mine, exploration and development work only was carried on during the year. Current reports, however, indicate that the progress of this work was so satisfactory that it was expected the mine would be in operation early in 1927 .

Near the head of Windham Bay, about 45 miles southeast of Juneau, renewed activity in gold-lode development was reported. 
Gold-bearing veins have been mined on this bay at intervals since 1900 , but though many of the veins carry visible gold, most of them are so small that they can not be mined separately, and if much country rock is included the value of the product becomes so low that heretofore mining it has not been found profitable. Some 30 claims have now been acquired by the Jacob Marty Mines and are being prospected with a view to mapping out.a program of work. During the year about 1,000 feet of drifts and crosscuts were driven, and after plans have been perfected the owners propose to operate the property actively in 1927.

About 15 miles west of Juneau, on the west side of Admiralty Island near its northern extremity, are Funter Bay and Hawk Inlet. Gold-bearing veins occur near the southern shore of Funter Bay, and probably the same zone of mineralization extends to the divide between the head of Hawk Inlet and Young Bay. A 50-ton Lane mill was sent in early in the spring of 1926 and was erected, so that by midsummer it was practically complete. Some prospecting work was allso done at the properties of the Alaska-Dano mines near Funter Bay, but no production was reported by that company. Near Slocum Arm, at the south end of Chichagof Island, some prospecting has been done on gold-quartz veins.

Gold-lode mining in the Prince William Sound region has always contributed a small amount of gold to the total lode production of Alaska. There are a number of places where gold-bearing lodes have been found, and at several.places prospecting and exploration work is still being carried on. At the Ramsay-Rutherford mine, east of Valdez Glacier, a small amount has been produced each of the last three years, and it is currently reported that during 1926 additional supplies and-equipment were freighted to the mine and further development work undertaken.

On Mineral Creek, a short distance west of Valdez, some exploratory work was done on the claim formerly known as the Little Giant mine and on the ground of the Ethel Mining Co., but no production was reported. Little more than assessment work is said to have been done on some quartz veins in the vicinity of Shoup Glacier. It is currently reported that the famous Cliff mine, near Valdez, was taken over by a new company known as the Cliff Mines, Inc., and that active exploration and construction work was to be undertaken as rapidly as possible in the hope that the mine would be in productive operation in 1927.

North of Valdez in the Tiekel district three small parties of prospectors were searching for workable quartz veins. At the time this district was visited by a member of the Geological Survey prospecting was being done on Stuart, Boulder, and Hurdle Creeks. In the Port Wells district three outfits are said to have been carrying on 
prospecting work during the summer on properties of the Alaska Glaciers Mining Co. and the Culross Island Mining Co., and the old Herman-Eaton mine. In the McKinley Lakes region, east of Cor dova, considerable local interest has been shown in the revival of explorations by the Lucky Strike Syndicate on gold-lode claims in that region.

In the Nuka Bay region, near the southern tip of Kenai Peninsula prospecting for gold lodes was continued. Although many promising indications have been found, the only mine from which any considerable production of gold was reported was on the Paystreak claim of the Alaska Hills Mines. This mine increased its output considerably over the preceding year and appears to have had an especially successful season, being enabled to run practically without interruption from early in May until November.

On Kodiak Island the Katmai Mining Co. has carried on some prospecting on quartz veins near Uyak. The company has acquired the old stamp mill at Uyak and plans to begin productive mining as soon as the necessary development work can be completed. In the northern part of Kenai Peninsula the Lucky Strike mine of the Alaska Minerals Co. was in operation much of the season and carried on mining on about the same scale as for several years. A small amount of exploratory work, which yielded a little gold, was also reported in the vicinity of Moose Pass. In the Girdwood district, at the head, of Turnagain Arm, some development work has been done on the quartz claims near the head of Crow Creek. Plans have been perfected for equipping the property of the Monarch Mining Co., which has been working on certain of the old Barnes claims, with additional machinery. Even the primitive methods heretofore employed have resulted in yielding encouraging amounts of gold. A little prospecting was also done by others in the same district.

The Willow Creek district, north of the head of Cook Inlet, is the largest of the gold-lode camps outside of southeastern Alaska and produced in 1926 gold valued at $\$ 334,000$. The principal mines in this district are those of the Willow Creek Mines (Inc.), the Fern Gold Mining Co., and the Mabel Mining Co. A number of other properties are being prospected by small groups of miners, and the organization of several new companies to develop old properties is reported. Among these may be mentioned the Alaska Free Gold Mining Co. and the Marion Twin Mining Co. No notable new developments were reported at any of the mines during the season. In the Fern mine a fault was encountered which cut off the ore for a short distance, but the ore was soon picked up again on the other side and is said to be of fully as high grade as heretofore. The continued success in following the veins in depth should serve to set at rest the former belief of many that all the veins in this district are only 
surficial and do not continue deep enough to justify extensive mining operations.

Some prospecting has been done on the gold lodes in the Valdez Creek region, near the head of Susitna River and about 50 miles east of Cantwell on the Alaska Railroad. No details of the results of this work are available, but apparently progress has been satisactory, as the owners are continuing the work.

Gold lodes in the vicinity of Fairbanks may be grouped more or less distinctly into two principal areas. One of these lies on the flanks of Ester Dome, to the west of Fairbanks, and the other is adjacent to Pedro Dome, northeast of the town. Productive mining has been in progress at both of these tracts on about the same scale as heretofore. The largest production in the western group came from the Mohawk mine, on St. Patrick Creek, and the largest in the eastern group came from the Crites \& Feldman property, on Moose Creek, a tributary of Fairbanks Creek. Most of the gold from all these properties is free and is readily recovered by amalgamation. Some of the veins contain sulphides, including stibnite (the sulphide of antimony), and the richest ore is usually found in close proximity to lenses and masses of these minerals, especially in those places where the veins are narrow. Some of the concentrates from one of the mines near Ester Dome was shipped to the States for smelting. The principal new activity in lode mining in the Fairbanks region in 1926 was the work done by the Elmes Gold Mining Co. on its property on Happy Creek east of Ester Dome. Besides carrying on exploration work for the development of the mine the company purchased the old custom 10-stamp mill that was formerly at Chena and installed it at the mine. As the preliminary work on the propperty is said to have been completed, active productive work should show a marked increase in 1927.

The mine of the Cleary Hill Alaska Mining Co. on Bedrock Creek, formerly the Rhoades-Hall mine, was the scene of some development work during 1926, but apparently the operators have not yet put the property into such shape as to afford any considerable production. A short distance farther up Bedrock Creek a little work was done intermittently on the property of the Wyoming Quartz Mining Co., and a small amount of gold was produced. Some work is also reported to have been done at the old Spaulding mine, fon Dome Creek. Assessment work and some prospecting were done on a number of the quartz claims throughout the Fairbanks district, but, so far as can be learned, they did not materially affect the total production of gold or disclose any noteworthy new occurrences of veins. 
A little prospecting for gold lodes has been reported at a number of other scattered points in Alaska, including the Koyukuk, Seward Peninsula, Jack Wade Creek in the Circle district, near Richardson, about 60 miles east of Fairbanks, and Kuskokwim Valley near Akiak. None of the work, however, appears to have uncovered any new deposits that seem to hold promise of developing into productive mines in the near future, though at many places veins that might be successfully mined in a less remote region have been found.

\section{GOLD PLACERS}

\section{GENERAL FEATURES}

Placer mining in Alaska showed a notable increase in activity in 1926. This increase was most obviously marked by a gain in the amount of gold produced, but it was also clearly shown by the number of projects under way which were approaching the productive stage though they had not yet reached it. The present trend of the placer industry is toward the development of large areas of relatively low-grade deposits where the installation of elaborate and expensive plants permits the cost of mining to be cut to so low a figure that the margin of profit is as much or even more than when high-grade ground was worked at high cost in less volume. Doubtless this condition will become more and more accentuated as time goes on, and in a measure it discourages the old type of prospector and operator, but it by no means indicates that the day of the prospector in Alaska is past. There still remain many areas where intelligent prospecting should handsomely repay the effort, though not in the same degree as in the boom bonanza days, when in places gold could be found from the grass roots down.

Perhaps one of the most healthy aspects of the modern placer industry in Alaska has been the growing recognition of the need of planning the work carefully in advance. Nowadays there are fewer instances of the installation of expensive plants which subsequently are found to be ill adapted to the work or placed on ground of too low a tenor to be mined at a profit. In the past the failure of such poorly planned enterprises has served to deter others that might have been successful, and, conversely, each successful enterprise has been almost certain to stimulate others to try similar projects. It seems certain, therefore, that as the success of many of the large projects which are now producing or under way is demonstrated, large-scale placer mining enterprises will for many years recover annually great quantities of placer gold with which parts of Alaskan are so richly endowed.

In preparing a general summary of the placer industry all available sources of information that might afford accurate data on the 
production of the year have been utilized. As a result it is believed that the figures for the total production given in this report are in as close accord with the facts as it is possible to make them. It should be realized, however, that in trying to get details regarding the hundreds of properties many sources of inaccuracy arise. For instance, among the small operators in remote districts the reported value of the gold sold to the local trader or passed on in exchange is not usually determined accurately, but is a more or less fictitious value, which may include even the charges for handling. The current price is seldom the same as the mint value. Furthermore, in reporting the value of gold many of the small operators fail to give the basis they used in determining it. Therefore, to estimate the value it is often necessary to assume that the gold produced by such operators has the same fineness as gold from some near-by claim, though it is recognized that no two lots of gold, even from the same claim, have precisely the same fineness and value. Then, again, there are still a number of operators who furnish no report at all, and consequently their production must be determined from some less authoritative source than from the man who best knows the facts. For these reasons it is felt that the correct distribution of the total placer-gold production among the different regions and districts may involve considerably greater error than the determination of the total value of production, though efforts have been made to guard against such inaccuracies. Owing to these uncertainties it has not seemed justifiable to attempt to state estimates for the different districts closer than the nearest thousand dollars, even though many of the data on which the computations were based were carried out to the nearest dollar.

The accompanying table presents in summary form the estimated production of placer gold in the different districts in 1926 and, for comparison, the production of the same districts in 1925 and the relative increase or decrease in 1926.

Statistics of placer mining in Alaska in 1925 and 1926

\begin{tabular}{|c|c|c|c|c|c|}
\hline \multirow[b]{2}{*}{ Region } & \multicolumn{2}{|c|}{$\begin{array}{l}\text { Number of } \\
\text { mines }\end{array}$} & \multicolumn{3}{|c|}{ Value of gold produced } \\
\hline & 1925 & 1926 & 1925 & 1926 & $\begin{array}{c}\text { Decrease or } \\
\text { increase, } \\
1926\end{array}$ \\
\hline 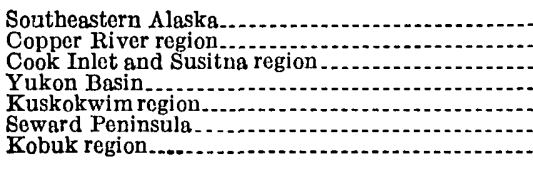 & $\begin{array}{r}5 \\
14 \\
33 \\
348 \\
21 \\
78 \\
8 \\
\end{array}$ & $\begin{array}{r}6 \\
14 \\
38 \\
293 \\
20 \\
75 \\
9\end{array}$ & $\begin{array}{r}\$ 5,000 \\
144,200 \\
214,400 \\
1,564,600 \\
191,400 \\
1,088,500 \\
14,900 \\
\end{array}$ & $\begin{array}{r}\$ 8,000 \\
102,000 \\
126,000 \\
1,529,000 \\
124,000 \\
1,873,000 \\
7,000 \\
\end{array}$ & $\begin{array}{r}+\$ 3,000 \\
-42,200 \\
-88,400 \\
-35,600 \\
-67,400 \\
+784,500 \\
-7,900 \\
\end{array}$ \\
\hline & 508 & 455 & $3,223,000$ & $3,769,000$ & $+546,000$ \\
\hline
\end{tabular}


From this table it will be apparent that the total production showed a marked increase, though from most of the districts, except Seward Peninsula, the production was about the same or less than in 1925. No general reason can be advanced to explain the decreases noted. Possibly the best general explanation is furnished by the extremely dry period that prevailed through most of the central and western part of the Yukon Valley and also in the Kuskokwim Valley, especially during the summer when placer mining is most active. Other and more local causes are noted in the following discussion of the mining activities in the different regions.

\section{SOUTHEASTERN ALASKA}

Topographically and geologically southeastern Alaska is relatively unpromising as a placer region because most of its shore line is abrupt, with only infrequent and narrow beaches, and its larger valleys in the recent past have been occupied by glaciers that carried away or disturbed any placer deposits that formerly may have been there. In spite of this general unfavorable character, placer deposits have been mined in the past at a number of places and during 1926 at a few places, the most notable of which were in the Silver Bow Basin near Juneau, at the property of the Porcupine Mining Co. on Porcupine River, and at the beach deposits near Yakataga. Work in the Silver Bow Basin and on the Yakataga beach was carried on at about the same rate as formerly. On Porcupine River, however, extensive work was in progress on the property of the Porcupine Mining Co., preparatory to hydraulic mining. A high-level flume to furnish sufficient water for a number of giants was under construction. Farther up Porcupine River, on the property of the Gold Nugget Mining Co., development work with a force of six men was reported to be making satisfactory progress.

\section{COPPER RIVER REGION}

Most of the placer gold produced in the Copper River region was taken from deposits on Dan and Chititu Creeks, in the Nizina district, and from Slate Creek, in the Chistochina district. On each of ( these streams the main production came from a single mine, though there were from two to three small operators on each stream who probably made the same or a little more by their mining and prospecting than they could earn in wages. The production at all these larger mines was considerably less than in 1925 . In practically all the mines this decrease was due to local accidents that should not affect the production another year. For example, at the upper camp on. Chititu Creek an extensive landslide occurred which took the men 
nearly all summer to remove, so that it was late in the fall before productive mining was again under way. On Dan Creek considerable dead work had to be done before the mine was in condition to produce at as high a rate as formerly. In the Nelchina district practically all the productive placer mining was on Albert Creek, but although three separate claims were mined the output of none of them exceeded a few thousand dollars. In the vicinity of Tiekel, north of Valdez, a little placer mining was in progress.

\section{COOK INLET-SUSITNA REGION}

In the Cook Inlet-Susitna region are included the placer camps in Kenai Peninsula and adjacent country, the Valdez Creek district, and the Yentna and Cache Creek districts. The total production from this region showed a decided decrease from the output in 1925 . This decrease, however, does not indicate that there was a real falling off in the activity of the camps, but rather that 1925 was a year of exceptionally large production. The area including the Yentna, Cache Creek, and Fairview districts continued to furnish the greatest amount of placer gold, though their production fell off most, principally owing to the lack of rain early in the season whereby little productive mining could be done for more than a month, and to an accident to the dredge whereby it ceased operations about a month earlier than it normally would. In spite of these handicaps there was evidence on many of the streams of increased placer activity. A large new hydraulic plant was installed on Falls Creek, and equipment has been taken into the district to hydraulic some of the high benches on Cache Creek itself. Mining on Nugget Creek still continued to yield good returns. Nearly a score of smaller plants were busy during the season on almost all the well-known creeks. In the Fajrview district a small amount of prospecting was done on Mills, Cottonwood, and Pass Creeks.

In the Kenai district, which was second in the Cook Inlet-Susitna region to the Yentna-Cache Creek area in production, the greatest amount of placer mining was done at the claims of the Mathison Mining Co. on Resurrection River, at the Holmgren \& Erickson mine on Crow Creek, north of Girdwood on Lynx Creek, and at the Belmont property on Bear Creek. In addition, there were seven other smaller camps which took out some gold ranging in value from a few dollars to a thousand dollars. The completion of a high-level ditch to supply water to Mathison Bros.' ground was the most extensive construction enterprise that was reported in the district.

Prospecting and development work was continued in the Valdez Creek region by several small parties of prospectors on the main 
stream and its tributaries from the south-Timberline, White, and Lucky Creeks. The largest amount of gold was produced by five men who were mining on the property of the McKinley Gold Placers Co. on Valdez Creek. Construction work on a ditch which is to bring water to the bench claims near the mouth of Valdez Creek occupied the time of one of the operators during most of the open season. Although little productive mining was in progress, the properties should be in good shape for another year.

\section{YUKON VALLEY}

In the Yukon Valley placer mining has been carried on at times in the past on almost all the tributary streams, and a few prospectors or miners may still be found even in the remoter parts of the region as well as in the more settled and developed camps. The determination of the actual production of each of the districts in the Yukon Valley has involved more uncertainty than that for many other parts of Alaska, because of the wide distribution of the camps and because of the failure of many operators to supply the essential data. However, the figure stated for the total production is believed to be correct within a small limit of error. The total placer production from all the districts in the Yukon Valley in 1926 was $\$ 1,529,000$, as against $\$ 1,564,600$ in 1925 . This apparent decrease is less than $21 / 2$ per cent, and in view of the uncertainties noted above it may be said that the production in the two years was essentially identical.

For convenience in description 17 separate districts have been recognized and the mining developments in each summarized in this report. Many of these districts do not correspond with the legal or recording districts, but they are intended only to serve as a convenient means of grouping the scattered properties into more or less related units. These districts are here named for some distinctive natural feature, as Koyukuk, or for the principal settlement near the mines, as Eagle, Fairbanks, or Rampart.

In the accompanying table the several districts are arranged in the order of their placer-gold production in 1926. Two small districts have been grouped with larger ones-Richardson with Fairbanks and Chandalar with Koyukuk-and the two small districts Kantishna and Bonnifield have been grouped together, but the production of no such small district has been more than $\$ 10,000$ and that of some was only a few thousand dollars. The combination has therefore not affected the relative standing of the larger districts, but it has been necessary in order to avoid disclosing confidential information as to the production of the individual miners in the smaller districts. 
Placer gold produced in Yukon Basin, 1925 and 1926, by districts

\begin{tabular}{|c|c|c|c|c|}
\hline \multirow{2}{*}{ District } & \multicolumn{2}{|c|}{ Value of gold } & \multicolumn{2}{|c|}{$\begin{array}{l}\text { Number of } \\
\text { mines }\end{array}$} \\
\hline & 1925 & 1926 & 1925 & 1926 \\
\hline $\begin{array}{l}\text { Fairbanks and Richardson } \\
\text { Innoko } \\
\text { Iditarod } \\
\text { Circle } \\
\text { Tolovana } \\
\text { Koyukuk and Chandalar } \\
\text { Hot Springs } \\
\text { Fortymile } \\
\text { Ruby } \\
\text { Eagle } \\
\text { Chisana } \\
\text { Rampart... } \\
\text { Kantishna and Bonnifield } \\
\text { Marshall }\end{array}$ & $\begin{array}{r}\$ 520,800 \\
167,500 \\
223,100 \\
149,600 \\
194,100 \\
57,800 \\
73,200 \\
39,800 \\
39,900 \\
35,000 \\
24,000 \\
8,000 \\
21,900 \\
9,900\end{array}$ & $\begin{array}{r}\$ 468,000 \\
242,000 \\
196,000 \\
162,000 \\
148,000 \\
73,000 \\
65,000 \\
60,000 \\
36,000 \\
28,000 \\
18,000 \\
12,000 \\
14,000 \\
7,000\end{array}$ & $\begin{array}{r}58 \\
16 \\
17 \\
35 \\
19 \\
34 \\
19 \\
58 \\
24 \\
12 \\
6 \\
7 \\
29 \\
12\end{array}$ & $\begin{array}{r}59 \\
16 \\
15 \\
23 \\
18 \\
28 \\
13 \\
42 \\
13 \\
12 \\
5 \\
13 \\
23 \\
13\end{array}$ \\
\hline & $1,564,600$ & $1,529,000$ & 348 & 293 \\
\hline
\end{tabular}

It is evident that the district near Fairbanks still surpasses all the other districts in the Yukon Valley in the value of its placer-gold production, in spite of the fact that in 1926 it showed the greatest falling off in comparison with 1925 of all the districts in the Yukon Valley. It not only produced the most gold but was the scene of the most active mining development. The construction work that was completed or in progress during 1926 gives every assurance that this district is entering on a period of revived mining enterprise which, though perhaps not as spectacular, may rival in results the boom days of the camp between 1903 and 1910 .

The most notable work that actually yielded gold in the district during the year was probably the construction and operation of the dredge on Nome Creek, a tributary of Beaver Creek about 40 miles north of Fairbanks. Further data regarding. the dredge are given in a later section of this report (pp. 28-32) in which dredging operations in the entire Territory are discussed. Although the completion of this dredge was of most immediate importance in swelling the output of gold, it was of much less significance to the general development of the district than the huge operations in progress by the Fairbanks Exploration Co. This company, which has acquired enormous tracts of placer ground throughout the region near Fairbanks, is putting its property into shape for economical large-scale mining with the most approved mechanical and other appliances. A single item in the plan of development is the bringing of large quantities of water from Chatanika River near Faith Creek to the company's properties on Goldstream, Cleary, and near-by creeks. This project alone is said to require the building of an open ditch 12 feet wide at the bottom for a distance of about 72 miles, the con- 
struction of a number of siphons whose combined length is more than 6 miles, and the driving of a rock tunnel for nearly threequarters of a mile. All this work has not only given employment to hundreds of men but is a sure guaranty of the mining activity that will follow the completion of these systematically and carefully worked out plans, which have been undertaken only after detailed and comprehensive testing of the ground that is to be mined.

Elsewhere in the Fairbanks district mining proceeded on about the same scale and in about the same valleys as formerly. The Tanana Valley Gold Dredge Co.'s dredge on Fish Creek, which was finished too late in 1925 to afford any production in that year, was operated for about 60 days. Dredging was also continued on Fairbanks Creek and Chatham Creek by the Fairbanks Gold Dredging Co. and the Chatham Gold Dredging Co., respectively, and a good season was reported by both. Drift and hydraulic mining was most active west of Fairbanks on Ester Creek and its tributaries and north and east of Fairbanks on the famous gold-producing streams of the past, which head near Pedro Dome, or the ridge that extends to the northeast and southwest from the dome, notably Eldorado, Cleary, Vault, Fairbanks, Pedro, and Fox Creeks.

In the Richardson district, which has been included in this report with the Fairbanks district, placer mining was done on Democrat and Tenderfoot Creeks, but the production of most of the individual camps was only a few hundred dollars each. Prospecting was also reported on Savage, Jarvis, and Redemption Creeks and Goodpaster and Volkmar Rivers.

In the Innoko district the small operators experienced great difficulty because of the dry season, which prevented sluicing at some of the claims until late in August. The larger part of the production, I however, is mined by four dredges, two of which, one on Yankee Creek and one on Little Creek, are owned by the Flume Dredge Co.; one on Ganes Creek is owned by the Innoko Dredging Co. and was leased to Frank Joaquin; and one on Ganes Creek was operated by Guinan \& Ames. Although the results obtained by the dredges appear good, most of the operators think that next year's output should be even better, because most of them started late, and the Guinan \& Ames dredge discontinued work early in September. At the Yankee Creek dredge a good deal of time was lost, as it was necessary to dig through old tailings, and at the Little Creek dredge considerable reconstruction work was done. Next to dredging the most productive mining was done on Ophir Creek, where four separate companies were at work. Two open-cut mines were worked on Little Creek, and one each on Spruce Creek, Victor Gulch, and Ganes Creek. 
Shortage of water interfered seriously with many of the open-cut placer mines in the Iditarod district during the height of the mining season, though both early and late in the season there were heavy rains. Not only did the drought interfere with the small mines, but it is said to have necessitated the closing down of one of the dredges a month earlier than usual. Most of the placer gold produced in the Iditarod district was mined by two dredges, both digging near Flat on Otter Creek. In spite of the dry season the total production from the dredges in 1926 was reported to have been more than in 1925, and so the falling off in the production of the district as a whole is attributable to decreased production from the open-cut mines. The greatest number of open-cut mines were on Willow, Flat, Chicken, Otter, and Granite Creeks, but some production was also reported from Malamute Pup and Happy Creek.

In the Tolovana or Livengood district placer mining was reported at 18 properties, most of which were on Livengood Creek itself, though considerable gold came from Olive, Ruth, and Lillian Creeks and some from Amy and Wilbur Creeks. Nine of the mines are drift mines that are worked mainly during the winter and the dumps sluiced during the summer, but in two of them underground work was continued practically throughout the year and in two only summer drifting is reported to have been done. Some prospecting by drilling was done on Olive Creek.

In the Circle district there was a little more placer gold produced in 1926 than in 1925. By far the larger part of the gold was mined by the J. C. Berry dredge on Mastodon Creek and the Berry Holding Co.'s hydraulic plant on Eagle Creek. In addition considerable lydraulic mining was done by two plants on Mastodon Creek, and i smaller open-cut mines were active on many of the other streams. It is currently reported that an examination has been made of parts of Birch Creek to determine whether it is suitable for dredging. The region in the past has been greatly handicapped by inadequate transportation facilities, but the approaching completion of the Fairbanks-Circle road is hailed by the larger operators as of inestimable value in the further development of the region. As an illustration, it is stated that even in the uncompleted condition of this road the trip has been made over it from Eagle to Fairbanks by automobile and horseback in 17 hours.

Placer mining in the Koyukuk district was highly successful in 1926, and all indications point to even more active work in 1927 . The greatest amount of gold came from Nolan Creek and its tributaries, but a number of prospectors were widely scattered through the region. Probably the most significant new development in the region was in the area between Nolan Creek and Hammond River. 
At this place, it is reported, a strong company has acquired a large number of claims which it proposes to mine on a large scale. It was contemplated that a large part of the preparatory work of putting these claims in shape for mining would be accomplished in 1926. The extremely low stage of the Koyukuk above Bettles prevented freighting in the necessary supplies and equipment, however, so that work on the claims was abandoned until 1927. In the meantime the ground was examined by the company's engineer and plans were formulated. A part of the project of developing these claims, it is understood, contemplates the construction of a ditch probably 45 miles long to take water from the upper part of the North Fork of Koyukuk River and carry it to the benches on Hammond River and Nolan Creek.

In the Chandalar district, which has been grouped for convenience with the Koyukuk district, relatively little placer mining was done in 1926. The only mining reported was some winter work on Little Squaw Creek and summer work on Big Creek. It is said that a radio station was installed at Little Squaw, as well as an airplane. landing field.

A small decrease in production from the Hot Springs district may perhaps be best accounted for by the fact that a considerable area, formerly productive, was temporarily lying idle, as it had been acquired by the American Creek Dredging Co. and is to be later dredged. Although perhaps this slightly reduced productive mining in 1926, it only means increased mining in the future. Placer mining in the district was most active on Woodchopper Creek, but considerable gold was recovered from benches on Eureka Creek and from the stream deposits on Pioneer, Cache, and Omega Creeks and New York Gulch.

In the Fortymile district water for placer mining was unusually abundant, and in consequence the camps produced considerably more gold than in 1925. The largest mine in the district is operated by the Walker Fork Mining Co. on Walker Fork. The principal other producing mines are on Jack Wade, Chicken, and Canyon Creeks and Fortymile River. Smaller amounts of mining work were in progress on Franklin, Napoleon, and Engle Creeks, and Myer and? Mosquito Forks. A number of prospectors were on several of the other creeks, but so far as can be learned they took out only a little gold.

Placer mining in the Ruby district was somewhat less active than in 1925, probably because of the dry weather which prevailed during much of the early part of the season. As has been the condition for several years past, the bulk of the production for the district came from Poorman Creek. Other creeks on which mining was 
reported are Flat, Timber, Bear Pup, and Greenstone, but a little prospecting that yielded a few hundred dollars each was done on a number of other streams. According to current report, options have been taken on a number of the claims on Long Creek, evidently with a view to undertaking some large-scale mining if suitable arrangements can be made.

Like the other districts in the eastern part of the Yukon Valley in Alaska, the Eagle district reported an unusually abundant water supply for placer mining in 1926. In spite of this condition the amount of gold produced in that year appears to have been somewhat less than in 1925. The largest amount of gold was mined by the Fourth of July Placers Co., but a considerable production was reported from Dome, Alder, American, and Crooked Creeks and a small amount from Fox, Barney, and Nugget Creeks and Lucky Gulch. Altogether 13 separate mining operations yielded some placer gold during the year.

Little definite information has been received concerning the placer production in the Chisana district during 1926. Apparently only five operators, on Bonanza and Little Eldorado Creeks, were working in the district during the season. The total production was evidently somewhat less than in 1925 .

More placer gold was produced in the Rampart district than in 1925. The greater part of it came from a number of small plants, most of which produced only a few hundred dollars each. Little Minook Creek yielded the largest amount, but work was also done on Hunter, Mason, Hoosier, and Slate Creeks.

Placer mining in the Kantishna district was carried on by 13 small camps, none of which produced more than a few thousand dollars and most of them only a few hundred. The largest amount of gold came from claims on Eureka, Glacier, Little Moose, and Glenn Creeks. Some placer mining was also reported on Crooked, Moose, Yellow, and Caribou Creeks.

Only a small amount of placer gold was produced in the Bonnifield district in 1926. From current reports the miners were first hampered by lack of water, but later flooded with too much. None of the operators who have reported their production to the Geological Survey took out much more than a thousand dollars in gold, and most of them took out only a few hundred dollars. The total production was small, as less than 10 outfits are known to have been at work in the region.

In the district here called the Marshall district placer mining was carried on at three more or less widely separated areas-one a few miles east of Marshall, or the post office of Fortuna Ledge; one adjacent to Kako Creek, which enters the Yukon about 15 miles north of 
Russian Mission; and one on Stuyahok River, about two-thirds of the distance between Marshall and Anvik. At 12 different camps in this district some placer mining was done. In the area nearest to Marshall the greatest amount of work was on Willow Creek, but the production was small, as on the principal claim much of the season was spent in construction.

\section{KUSKOKWIM REGION}

There are three principal districts included in the Kuskokwim region where placers were mined in 1926. These for convenience may be called the Goodnews Bay district, the Tuluksak-Aniak district, and the Mount McKinley district. Goodnews Bay is on the east side of Kuskokwim Bay about 40 miles north of Cape Newenham. Tuluksak River enters the Kuskokwim from the east about 30 miles northeast of Bethel, and Aniak is the name of a river and small settlement about 80 miles northeast of Bethel. In the Tuluksak-Aniak district, as the term is here used, is included the Georgetown district, which is named for a river and town that are 40 to 60 miles upstream from Aniak and about 50 miles south of Iditarod. The Mount McKinley district embraces all the eastern part of the Kuskokwim Valley, but the mining work in it is more or less localized near McGrath and Takotna.

By far the larger part of the placer gold taken from the Kuskokwim Valley in 1926 was mined by two dredges-one on Bear Creek, in the Tuluksak-Aniak district, and the other on Candle Creek, near McGrath. The Bear Creek dredge was constructed during 1925 but first began to mine gold in 1926. It is owned and operated by the New York Alaska Gold Dredging Co. The ground which the dredge mined had been carefully prospected before the dredge was built, so that the company could forecast in advance closely what the results would be. However, it is highly gratifying that the work turned out so successfully from the very start. The Candle Creek dredge of the Kuskokwim Dredging Co. was in operation only part of the season, so that its production was much less than it was last year. In addition to operating the dredge in the Tuluksak-Aniak district it is currently reported that the same company acquired a considerable tract of placer ground on the west side of Bear Creek that is suitable for: hydraulicking and was constructing a ditch line 2 or 3 miles long to this tract. This hydraulic plant will be operated entirely separate from the dredge, and when work there is under way it should materially increase the production of the district. Open-cut mining was done on Canyon Creek and on several of the other tributaries of Tuluksak River and on Donlin Creek north of Georgetown. 
In the Goodnews Bay district only five small placer mines were in operation during 1926. The greatest amount of gold was derived from placers on Watermuse Creek. Some gold was produced from claims on Kowkow, Butte, Olympiac, and Bear Creeks. The supply of water for sluicing was scarce, especially on Butte Creek, and on most of the others work was little more than prospecting.

In the Mount McKinley district, in addition to the dredging on Candle Creek, already noted, there were a number of sluicing and open-cut placer mines in operation. Among the most productive streams in the district were Hidden, Eagle, Ruby, and Birch Creeks. Mining was much hampered by lack of adequate supplies of water for sluicing and hydraulicking, as it was also in the near-by Innoko district.

\section{SEWARD PENINSULA}

Seward Peninsula was the one region in Alaska where there was a notable increase in placer production in 1926. This increase is largely attributable to the great amount of gold that was mined by dredges, as the production from that source alone represented many hundred thousand dollars more than the entire production of the peninsula in 1925. In fact, according to the published report of the Hammon Consolidated Gold Fields, its production was practically $\$ 1,200,000$, which shows that that company alone produced $\$ 110,000$ more gold than was taken out by all the mines in the region in the preceding year. $\circ$ More than 80 per cent of the placer production came from 18 dredges, one or more of which were active in almost every district. Additional data on the dredging activities in Seward Peninsula, as well as those in other parts of Alaska, are given in a later section of this report. In the relative order of their output of placer gold in 1926 the various districts of Seward Peninsula stood as follows: Nome, Fairhaven, Solomon, Council, Kougarok, Koyuk, Casadepaga, and Port Clarence. In all the districts water was scarce during a large part of the placer-mining season, and this condition was naturally felt most keenly by the smaller operators.

The outstanding item of significance in the Nome region was the mining activity of the Hammon Consolidated Gold Fields on its properties near Little and Wonder Creeks. Toward the end of the year considerable interest was shown in the reported find of a beach only a few feet above the level of the present beach in the region west and somewhat north of Nome. Further prospecting of this beach was to be carried on and, if the gold that has been found can be traced for any considerable distance, should furnish an important link in the geologic history of the region, in addition to swelling the production of gold. 
In the Fairhaven region likewise the outstanding item of the year is the increased dredge production. This is especially significant because one of the two dredges in that region was in operation only a short time, as it was being moved to another site, and the other dredge was handicapped because not enough thawing equipment was available at the beginning of the season to keep an adequate amount of ground thawed ahead of the dredge:

In the Inmachuk region the hydraulic plant that was in operation on Inmachuk River and that derives its water supply from a long ditch from Imuruk Lake was the largest operation of its kind on Seward Peninsula. Only a small amount of gold was mined in the Buckland River valley, although two parties put in most of the open season there.

The construction of the Goldsmith Dredging Co.'s dredge and the operation of this and the other dredges formed the most important activities in the Solomon district. The old Flower dredge of the Solomon Valley Dredge Co. was mining only a few days, and most of the season was spent in remodeling the dredge and installing a new bucket line and other equipment. The Loman dredge was out of commission the early part of the season, as it was damaged by ice and sunk. It was successfully raised, however, and put into condition, so that it was again mining by the 1st of July and continued throughout the rest of the season with satisfactory results.

In the Casadepaga district, which may be considered practically a part of the Solomon district, no new work was in progress during the year.

Early in 1926 considerable local excitement was aroused by the finding of some rich placer ground near Bluff, and for a short period a mild stampede followed. The excitement gradually died down, as it was found that only a small amount of gold had been produced. The largest amount of mining near Bluff was done by af scraper outfit on the beach opposite the mouth of Daniels Creek.

Placer mining in the Council district was done at practically the same places and on about the same scale as formerly. Three dredges were mining during most of the open season, though the Crooked Creek and Ophir dredges shut down rather early because of the dry weather. A reported find of some promising placer ground on Rock Creek, a tributary of Aggie Creek, revived interest in prospect-: ing in that region. The find of itself is apparently of only local interest, but it is significant as showing that there are areas even in as well-known districts as that near Council where placers may still be found that are worth investigating.

Placer operations in the Kougarok district were considerably hampered by the dry season. The principal interest in that camp ap- 
pears to have been in connection with the repair of the old tram line from Nome to Shelton and its possible extension to Inmachuk River and Candle. The result of the work already done on this tramway has been to reduce the cost of transportation between Nome and Shelton considerably, and this should be of great assistance in encouraging the undertaking of new prospecting and mining work:The Behring Dredging Corporation which has long been an actiye factor in the development of the district, reports that it has completed mining out its ground and has sold: off all its holdings, including. its ditch, and will discontinue operations in Alaska.

In the Koyuk district the only creeks from which any production of placer gold was reported were Dime Creek and its tributaries and Sweepstake Creek. Most of the operators were unable to accomplish much because of the shortage of water. Even the dredge was operated only a few days. It was reported that a hydraulic outfit was landed during the summer on the Koyuk ready to be hauled to Sweepstake Creek, where it was to be installed. About 10 separate mining parties did some work in the Koyuk district during the year, all operating open-cut mines, except one drift mine that was -worked during the winter.

In the Port Clarence district a little placer gold was mined on Bluestone River and some of its tributaries, especially Winty Creek and Gold Run, and on Coyote Creek. The unusually dry season, which made productive mining difficult, is said to have aided prospecting, inasmuch as ordinarily the prospectors are driven out by water before they are able to sink their test pits to bedrock. 'All the mining work in this district is small, and none of the mines produced more than a few thousand dollars in gold in 1926.

\section{NORTHWESTERN ALASKA}

The only district in northwestern Alaska in which any placer mining was reported in 1926 was the Kobuk. There are two principal areas in the valley of the Kobuk and its tributaries where placer gold is mined. The western one is near Squirrel River and Klery Creek, about 60 miles above the mouth of the river, and the eastern one is in the vicinity of Shungnak, in the central part of the Kobuk Valley, about 150 miles in an air line from the coast. Both of these areas are so remote from all ordinary means of transportation that their development is much hampered by high costs. In the Klery Creek region work amounted to little more than prospecting or the annual assessment work required by law. One of the miners in the district, however, has a drill rig which was brought in a few years ago and with. which he proposes to make some tests of 
the bench deposits, which are widespread in the region and in places have already been proved to carry gold.

The greatest amount of placer gold that is mined in the Kobuk district comes from half a dozen small parties of miners and prospectors who are developing ground in the vicinjty of Shungnak. The largest of these operations' is on California-Creek, where the placer is mined by hydraulic methods. The creek of second importance in this region is Dahl Creek, and here, too, the largest amount of work was done by' a hydraulic plant, although in the same villey there are serrail small outfits that are' shoveling the creek gravel into sluice boxes. Although there is indisputable evidence that placer gold is widely distributed in this region, its recovery is extremely costly not only because of the remoteness of the region but also because of the great number and large size of the boulders in the deposits that carry the gold. Furthermore, in most of the larger valleys the old placer concentrations have been in great part swept out or disturbed by the former glaciation of the region, and in the smaller valleys, where the other conditions are favorable, it, is usually difficult to get an adequate supply of water.

\section{DREDGING}

Over 60 per cent of the placer gold produced in Alaska in 1926 was mined by dredges-more than 45 per cent above the output from dredges in 1925. The total gold recovered by dredges in 1926 was $\$ 2,291,000$, of which more than two-thirds came from 18 dredges on Seward Peninsula and the rest from 14 dredges in other parts of Alaska. A comparison of the dredge production in 1926 with that of former years is afforded by the accompanying table, which gives the records back to 1903, the earliest year in which records of dredge production are available.

Gold produced by aredge mining in Alaska, 1903-1926

\begin{tabular}{|c|c|c|c|c|}
\hline Year & $\begin{array}{c}\text { Number } \\
\text { of dredges } \\
\text { operated }\end{array}$ & $\begin{array}{l}\text { Value of gold } \\
\text { output }\end{array}$ & $\begin{array}{l}\text { Gravel han- } \\
\text { dled (cubic } \\
\text { yards) }\end{array}$ & $\begin{array}{l}\text { Value of } \\
\text { gold re- } \\
\text { covered } \\
\text { per cubic } \\
\text { yard }\end{array}$ \\
\hline \multirow[t]{2}{*}{$\begin{array}{l}1903-1915 \\
1916\end{array}$} & \multirow[t]{2}{*}{$\begin{array}{l}34 \\
36 \\
28 \\
28 \\
22 \\
24 \\
23 \\
25 \\
27 \\
27 \\
32\end{array}$} & $\begin{array}{r}\$ 12,431,000 \\
2,679,000 \\
2,500,000 \\
1,425,000 \\
1,360,000 \\
1,129,932 \\
1,582,520 \\
1,767,753 \\
1,848,596 \\
1,563,331 \\
1,572,312 \\
2,291,000\end{array}$ & \multirow[t]{2}{*}{$\begin{array}{l}3,900,000 \\
3,700,000 \\
2,490,000 \\
1,760,000 \\
1,633,861 \\
2,799,519 \\
3,186,343 \\
4,645,053 \\
4,342,667 \\
3.144,624 \\
5,730,000\end{array}$} & \multirow[t]{2}{*}{$\begin{array}{r}\$ 0.69 \\
.68 \\
.57 \\
.77 \\
.69 \\
.57 \\
.55 \\
.40 \\
.36 \\
.50 \\
.40\end{array}$} \\
\hline & & $32,151,000$ & & \\
\hline
\end{tabular}


The total amount of gold produced by dredges since 1903 is about 15 per cent of the total amount of gold from all other kinds of placer mining since 1880 , but, with the constant increase in the proportion of gold mined by dredges during the last few years, the difference between the two totals is constantly becoming smaller.

In the foregoing table the yardage mined and the value of gold recovered per cubic yard as stated are open to some question, because several of the dredge operators have not furnished specific information on that subject for their individual properties, and the figures for these properties have therefore had to be estimated. In making these estimates the following procedure was adopted to determine the unknown factors: Operators of dredges that produced approximately $\$ 1,899,000$ in gold, or about 83 per cent of the total mined by dredges, report that that amount came from 4,756,000 cubic yards of gravel. The average yield thus shown is a little less than 40 cents in gold to the cubic yard. Applying this average to the unknown quantities, it follows that the total amount of material mined by dredges, if worth about 40 cents a yard, was 5,730,000 cubic yards, and this figure has been adopted in the table. This procedure is open to criticism because the companies which report fully the amount of ground mined were the larger ones and doubtless they worked lowergrade ground than the smaller companies. As a result the average value adopted may be too low and consequently give too large an amount of gravel mined. This method, however, has been followed for the last three years, so that the quantities and values given for 1926 are comparable with those reported before and are therefore for practical purposes essentially correct.

The length of time that different dredges were operated varied widely. The longest season reported was 167 days for one of the 1 Hammon Consolidated Gold Fields dredges at Nome, and the next longest was 155 days at the Fairbanks Creek dredge. The shortest season was at the Dime Creek dredge in Seward Peninsula, which operated only a few days. In general, the length of time that most of the dredges were operated was not determined by the cold or similar conditions that usually limit work in a northern country, but by some other cause, such as breakage or lack of water. According to the records the earliest date for the begimning of dredging in 1926 was May 5 at the Cache Creek dredge, in the Susitna region, and the latest dredging was done December 4 at the Hammon dredge at Nome. The New York Alaska Gold Dredging Co.'s dredge in the Tuluksak-Aniak district did not stop mining until November 28, and the Nome Creek dredge in the Fairbanks district was operated until November 8. The experience of this year as well as of former years has therefore shown that throughout most of the region in 
which dredges have been used an operating season of 150 to 165 days is entirely practicable for a well-equipped and skillfully managed dredge under normal conditions. In fact, the extremely long season reported. by the Hammon company could probably have been made still longer by starting earlier, as work there did not begin until June 20.

The following is a list of the Alaska dredges that did some productive mining during the year :

Cook Inlet and Susitna region:

Yentna district-

Cache Creek Dredging Co. (leased to Obermiller

\& Englehorn)

Cache Creek.

Yukon Basin:

Circle district-

C. J. Berry Dredging Co

Mastodon Creek.

Fairbanks district-

Chatham Gold Dredging Co

Cleary Creek.

Fairbanks Gold Dredging Co

Fairbanks Creek.

Nome Creek Dredging Co

Nome Creek.

Tanana Valley Gold Dredging Co. (Ltd.)

Fish Creek.

Iditarod district-

J. E. Riley Investment Co

Otter Creek.

North American Dredge Co

Otter Creek.

Innoko district-

Flume Dredge Co

Yankee Creek.

Flume Dredge Co

Little Creek.

Guinan \& Ames Dredging Corporation

Ganes Creek.

Innoko Dredge Co. (leased to Frank Joaquin)

Ganes Creek.

Kuskokwim region :

Mount McKinley district-

Kuskokwim Dredging Co

Candle Creek.

Tuluksak-Aniak district-

New York Alaska Gold Dredging Co

Bear Creek.

Seward Peninsula:

Casadepaga district-

Peck

Casadepaga River.

Council district-

Crooked Creek Dredging Co

Albion Creek.

Northern Light Mining Co

Ophir Creek.

Ophir Gold Dredging Co

Ophir Creek.

Fairhaven district-

Fairhaven Gold Dredging Co. (2) (leased to

Golden Centre Mines)

Kougarok district-

Behring Dredging Corporation

Candle Creek.

Kougarok River.

Koyuk district-

Dime Creek Dredging Co

Dime Creek.

Nome district-

Dexter Creek Dredging Co

Dexter Creek.

Dry Creek Dredging Co

Dry Creek.

Hammon Consolidated Gold Fields (1)

Wonder Creek.

Hammon Consolidated Gold Fields

(2)

Little Creek. 
Seward Peninsula-Continued.

Solomon district-

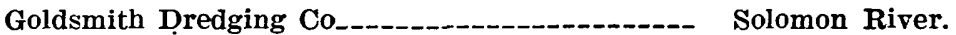

Peder Iverson_._._._.

Lomen Reindeer \& Trading Corporation

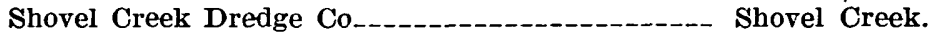

Solomon Valley Dredge Solomon River.

There were four new dredges operating in Alaska in 1926, some of which were built in 1925 but were not completed in time to do productive work in that year. The new dredges were the Nome Creek dredge and the Tanana Valley dredge, in the Fairbanks district; the New York Alaska Gold Dredging Co.'s dredge on Bear Creek, in the Tuluksak-Aniak district; and the Goldșmith dredge, on Solomon River. Possibly a record for rapid dredge construction belongs to the Goldsmith Co., for the material for its dredge did not arrive in Nome until the middle of June and was then taken to Solomon River, some 40 or 50 miles distant, and put together, and the dredge was said to be mining by August 23 and made a clean-up on September 4. Almost as rapid a record for construction was reported by the Nome Creek Dredging Co. in the Fairbanks district. All the new dredging companies reported a satisfactory season, though none of them was able to make a full season's run, owing to the construction or repair work which had to be done. These dredges will therefore attain a much higher production when they are broken in and utilize the full season available.

Several new dredging enterprises were discussed during the year, and some of them will doubtless be carried through. The most definite project of this sort was the organization of a company to build a dredge on American Creek, in the Hot Springs district of the Yukon region. Plans for this work have been developing for some time, and the ground which is to be mined has been tested, so that its gold content to maintain a dredge is demonstrated. The financing of the work has been arranged, and the dredge should have been in productive operation in 1926. No steps have yet been taken for constructing the dredges that will be built to mine the properties of the Fairbanks Exploration Co. in the Fairbanks region. Preparations for them are going ahead rapidly, and if the present plans of the company are adhered to, it will not be long before this huge undertaking reaches the productive stage. It is also reported that the Hammon Consolidated Gold Fields is contemplating the building of additional dredges in Seward Peninsula.

One of the difficulties that has been encountered in many of the Alaska dredging fields has been the permanently frozen condition of the gravel and the masses of interbedded ice in the deposits, which quickly wear out the bucket lifts and put strains on the machinery $6097^{\circ}-29-3$ 
that result in frequent breakage. It is found impracticable to dredge material of this kind without thawing. In the past, extensive plants to heat water or furnish steam have been necessary in order to prepare the ground for dredging. A few years ago, however, it was proved that the thawing could be done by cold water at a somewhat slower rate but at a lower cost. Extensive experimentation has been carried on by the Hammon Consolidated Gold Fields at Nome to determine the different factors affecting thawing by this means, and as a result the problem has been sufficiently solved, so that the company has adopted a more or less standard practice for preparing the ground in advance of its dredges. Of course not all the placer deposits in Alaska that are being dredged or that are suitable for this mode of mining are permanently frozen, and consequently many of them do not need any further preliminary preparation of the ground than would be required for dredging in the States or elsewhere.

A description of the mechanical features of many of the Alaska dredges, with much other valuable information on the cost and methods of all kinds of placer mining, has been recently published by the Bureau of Mines. ${ }^{5}$ Only those dredges which had been built in 1924 or prior to that time are included in the report, but the tabulation of all the pertinent factors regarding them has a great present-day value to anyone desiring information regarding the equipment and different types of deposits that have been mined.

\section{COPPER}

Deposits containing some copper minerals are found throughout Alaska from the extreme southern part of the Territory to Kobuk River and Seward Peninsula. Copper ore, however, is bulky in comparison with its value and requires considerable milling and metallurgical treatment to separate the metal from the gangue, so that unless the deposit is of especially high grade and exceptionally advantageously situated it is not adaptable to commercial development under present conditions. The gradual settlement of the country and the opening up of roads and increase of transportation facilities. will doubtless reduce some of the present high cost and thus permit the development of some copper properties that are now standing idle. At present, however, the greater part of the Alaskan copper comes from two mines in the Chitina Valley, in the Copper River region, that are operated practically as a single unit, and a mine on Latouche Island, all three operated by the Kennecott Copper Corporation. Considerable quantities of copper-bearing concentrates were shipped from the palladium mine of the Alaska Palladium Co. on

5 Wimmler, N. L., Placer-mining methods and costs in Alaska: Bur. Mines Bull. 259, 236 pp., 1927. Price 55 cents, from Superintendent of Documents, Government Printing Office, Washington, D. C. 
Prince of Wales Island, in southeastern Alaska. Small amounts of copper-bearing ore or concentrates were also received by the smelters from ores whose principal value came from some other metal, notably gold, silver, or lead. Such material was produced by mines in the Hyder district, in the vicinity of Ketchikan near Juneau, and in the Willow Creek district near Wasilla.

A statement of the quantity of copper produced from any region as a single figure without any accompanying explanation is likely to be misleading or valueless, because in all the processes that the ore undergoes from the time that it is broken in the mine until its metal content has been refined at the smelter there are inevitable losses, so that at each step the amount of copper differs. As a result the amount of copper which was in the ore when it reached the mouth of the mine is very different from the amount that is saved after it is concentrated by milling, and this amount is in turn very different from the amount of copper that is sold after smelting. An illustration of this condition is afforded by the published report of the Mother Lode Coalition Mines Co. ${ }^{6}$ in which the amount of ore mined during 1926 is stated to have been 140,033 tons, containing on the average 10.39 per cent of copper, which would have been equivalent to $29,098,857$ pounds of copper. According to the same report, however, shipments to the smelter contained only 27,228,240 pounds of copper. Evidently 1,870,617 pounds of copper that was originally in the ore was lost during the process of milling. As it stands, this is a large amount of copper, but it represents a loss of only 6.43 per cent of the original content, or a mill recovery of 93.57 per cent, which is an excellent record.

The total copper-bearing ore mined in Alaska in 1926 is estimated to have been 670,000 tons, which contained $72,000,000$ pounds of copper. This ore when concentrated and ready for shipment to the smelter had been reduced to approximately 95,000 tons, having a copper content of $67,778,000$ pounds of copper, which represents a recovery of over 94 per cent of the original copper content. For the purposes of the present report this quantity of copper is taken as being the output of the Alaska mines during the year.

In attempting to set a value for this copper many variables are introduced which create further uncertainties. Obviously the copper in the ore is not of itself worth the current market price of the metal, inasmuch as some is lost and that which is saved necessitates ,expenditure before it reaches the form of merchantable metal. The isame condition is true to a certain . extent of the copper in the ore that is sent to the smelter, but the losses as well as the charges are generally lower on this material, and consequently its value has

\footnotetext{
- Mother Lode Coalition Mines Co., Eighth Ann. Rept., for 1926, p. 3, 1927.
} 
been assumed to be the average market price at which copper sold during the year. The average price of all copper sold in 1926 in the United States, according to computations by the Bureau of Mines, was 14 cents a pound. The total value of the copper in the ore and concentrates shipped from Alaska during that year may therefore be taken as $\$ 9,489,000$. It is recognized that this figure does not take into account the fact that an efficient selling agent would undoubtedly take advantage of the fluctuations in the market price of copper and dispose of the product of his mine so far as possible during periods of high prices. That both the Kennecott Copper Corporation and the Mother Lode Coalition Mines Co. were fortunate in marketing their product is shown by the statements contained in their annual reports, which give their average selling price as 14.4 and 14.115 cents, respectively. If these figures had been used for the production of these companies, the total value above given would have been increased nearly $\$ 100,000$. The figures relating to value can not, therefore, be regarded as representing the amounts received by the producing companies or even the actual amounts received for specific lots of copper. They do, however, serve to represent within reasonable limits the approximate magnitude of the industry, and they indicate a falling off during 1926 of about $\$ 872,000$ from the production in 1925 .

Copper, silver, and gold produced at Alaska copper mines 1880, 1900-1926

\begin{tabular}{|c|c|c|c|c|c|c|c|c|}
\hline \multirow{2}{*}{ Year } & \multirow{2}{*}{$\begin{array}{l}\text { Mines } \\
\text { oper- } \\
\text { ated a }\end{array}$} & \multirow{2}{*}{$\begin{array}{l}\text { Ore mined } \\
\text { (tons) }\end{array}$} & \multicolumn{2}{|c|}{ Copper } & \multicolumn{2}{|c|}{ Silver } & \multirow{2}{*}{ Gold } & \multirow{2}{*}{$\begin{array}{l}\text { Total } \\
\text { value of } \\
\text { metals }\end{array}$} \\
\hline & & & Pounds & Value & Fine ounces & Value & & \\
\hline \multirow{14}{*}{$\begin{array}{l}1880 \\
1900-1915 \\
1916 \\
1917 \\
1918 \\
1919 \\
1920 \\
1921 \\
1922 \\
1923 \\
1924 \\
1925 \\
1926\end{array}$} & \multirow{14}{*}{$\begin{array}{r}18 \\
17 \\
17 \\
8 \\
8 \\
6 \\
5 \\
6 \\
5 \\
5 \\
5\end{array}$} & & 3,933 & $\$ 826$ & & & & $\$ 826$ \\
\hline & & $1,232,396$ & $220,773,969$ & $35,031,225$ & $2,351,726$ & $\$ 1,297,756$ & $\$ 1,059,357$ & $37,388,338$ \\
\hline & & 617,264 & $119,654,839$ & $29,484,291$ & $1,207,121$ & 794,286 & 188,977 & $30,467,554$ \\
\hline & & 659,957 & $88,793,400$ & $24,240,598$ & $1,041,153$ & 857,911 & 265,900 & $25,364,40$ \\
\hline & & 722,047 & $69,224,951$ & $17,098,563$ & 719,391 & 719,391 & 107,635 & $17,925,589$ \\
\hline & & 492,644 & $47,220,771$ & $8,783,063$ & 488,034 & 546,598 & 63,795 & $9,393,45 \mathrm{e}$ \\
\hline & & 766,095 & $70,435,363$ & $12,960,106$ & 682,033 & 743,416 & 18,868 & $13,722,390$ \\
\hline & & 477.121 & $57,011,597$ & 7,354, & 544,311 & 544,311 & 11,689 & $7,910,496$ \\
\hline & & 581,384 & $77,967,819$ & 10,525, & 623 & 623,518 & 15,069 & $11,164,242$ \\
\hline & & 731,168 & $85,920,645$ & $12,630,335$ & 715,040 & 586,333 & 33,633 & $13,250,301$ \\
\hline & & 761,779 & $74,074,207$ & 9,703 & 572,078 & 383,292 & 13,341 & $10,100,35$ \\
\hline & & 860,023 & & 10,361 , & & 412 & 32 , & 10,806 , \\
\hline & & 670000 & 67 & 10, & 605 & 377,600 & 40,000 & $9,906,60$ \\
\hline & & $8,572,300$ & $1,052,715,000$ & $187,663,000$ & $10,146,000$ & $7,887,000$ & $1,851,000$ & $197,401,000$ \\
\hline
\end{tabular}

a Properties producing less than $\$ 1,000$ are not counted as mines but are considered prospects.

No new developments of note were reported at the mines of the Kennecott Copper Corporation at Kennecott, in the Copper River region, during 1926. The ore from this property, as in the past, was largely high-grade copper sulphide and carbonate containing considerable silver but no gold. The highest-grade ore is sacked and shipped directly to the smelters, but the lower-grade ores are concentrated before shipment. According to the published statements 
of this company, ${ }^{7} 106,933$ tons of ore was mined during the year, which was estimated to have an average content of 13.07 per cent of copper and 261 ounces of silver to the ton. At the mine of the Mother Lode Coalition Mines Co., which is contiguous to the properties of the Kennecott Copper Corporation and is operated by that company, although the accounting and bookkeeping are conducted separately, the ore is essentially the same as at the other property, being a high-grade copper sulphide and carbonate containing considerable silver. The report of this company ${ }^{8}$ shows that during the year 140,033 tons of ore was mined, which had an estimated content of 10.39 per cent of copper and 174 ounces of silver to the ton. The result of exploratory work in searching for new ore bodies has not met with the success hoped for. According to the report of this company "no additional ore bodies have been found. In consequence the effect of mining operations throughout the year was to reduce the known reserves. Such ore reserves were depleted to an amount equal to about two-thirds of the year's production. The extent of this depletion was not greater for the reason that while practically no new ore was opened up the stopes produced a larger quantity of ore than was expected." ${ }^{9}$ Both of these large companies are keeping prospecting work actively under way and, it is understood, expect to utilize the new electrical methods of underground exploration extensively during the coming year.

The ore of the Beatson mine of the Kennecott Corporation, on Latouche Island, is entirely different from that of the mines in the Copper River region, just described. The ore produced is a lowgrade copper-iron sulphide and is mined by a system of caving. All the ore is concentrated at mills at the mine, and only the concentrates are shipped to the smelter in the States. According to the published report of this company ${ }^{10} 418,091$ tons of ore was produced in 1926, which had an estimated content of 1.67 per cent of copper and 0.325 ounce of silver to the ton.

The other mines that produced some copper but are valuable principally for some other metal are noted in the parts of this report in which the more valuable mineral is described. Thus the palladium mine from which some copper was produced has been included in the section describing the production of platinum metals, and the silver-lead ores from which some copper was extracted are noted in the sections describing those metals.

The Green Butte mine, on McCarthy Creek, a short distance east of the Kennecott group, which was actively operated in 1925, was idle

\footnotetext{
' Kennecott Copper Corporation Twelfth Ann. Rept., for 1926, p. 6, 1927.

${ }^{8}$ Mother Lode Coalition Mines Co. Eighth Ann. Rept., p. 3, 1927.

Idem, p. 3 .

10 Kennecott Copper Corporation Twelfth Ann. Rept., p. 6, 1927.
} 
most of the season of 1926 , the only work reported being surface maintenance. The ore from this property resembles the high-grade sulphide and carbonate ore of the mines near Kennecott and seems to occur under relatively similar geologic conditions. This property has been developed by an inclined shaft to a depth of 700 feet, and it is expected to resume production in the near future.

The operators of several properties from which no production was reported during the year appear to have been active in carrying on development and prospecting work. Among the most important of these activities were the developments on the Copper Creek mines, in the Kotsina district, where a considerable crew has been engaged in preparing for mining and installing the necessary machinery. Renewed activity was also reported on the property of the Alaska Nabesna Corporation, in the Nabesna district, where, it was stated, a drill rig had been taken with the aim of prospecting the ground more thoroughly. Little new prospecting is reported on the copper. properties in the vicinity of Prince William Sound. In several places some prospecting and the necessary assessment work had been done. Many of the properties in that region have already been patented, so that unless productive work is contemplated the property is allowed to lie idle, as desultory prospecting is not required to hold the ground. In consequence of the relatively low price of copper none of the companies seem to have considered development work at this time warranted. Although it is entirely probable that there are copper lodes in this region that may be commercially developed later, there is nothing to indicate that in the near future any of them will furnish notable additions to the Territory's copper production.

\section{SILVER}

Practically no ores are mined in Alaska solely for their silver content, and by far the greater part of the silver produced is recovered as a minor constituent in ores that are valuable chiefly for their copper. Productive mining of ores that are valuable principally for their silver content was done only in the vicinity of Hyder. In that region the ores from which much of the silver is recovered are dominantly lead ores in which the silver is less in quantity but higher in value.

Data regarding the production of silver in Alaska have been referred to in many of the preceding statements and shown in a number of the preceding tables, but for convenience the sources of the silver and the quantity and value of the production from each source are here set forth: 
Silver produced in Alaska in 1925 and 1926

\begin{tabular}{|c|c|c|c|c|}
\hline \multirow{2}{*}{ Source } & \multicolumn{2}{|c|}{1925} & \multicolumn{2}{|c|}{1926} \\
\hline & Ounces & Value & Ounces & Value \\
\hline \multirow[t]{2}{*}{$\begin{array}{l}\text { Gold lodes. } \\
\text { Gold placers } \\
\text { Copper and silver lead lodes }\end{array}$} & $\begin{array}{r}67,186 \\
24,144 \\
606,929\end{array}$ & $\begin{array}{r}\$ 46,445 \\
16,756 \\
419,294\end{array}$ & $\begin{array}{r}59,940 \\
24,870 \\
605,190\end{array}$ & $\begin{array}{r}\$ 37,400 \\
15,500 \\
377,600\end{array}$ \\
\hline & 698,259 & 482,495 & 690,000 & $430 ; 500$ \\
\hline
\end{tabular}

Prospecting and development of the silver-lead ores in the Hyder district has gone on somewhat more actively than heretofore, but the largest production still comes from the Riverside mine, a short distance northwest of Hyder. The company operating this mine concentrates its ore in its own mill and ships the product to a smelter in the States. In addition to the silver and lead the ore carries considerable gold, some of which is recovered in the course of the milling operations. In many of the veins in the Hyder district distinct silver minerals are found, and in some of the similar veins in; adjacent parts of British Columbia these minerals are important constituents of the ore. Consolidation of a number of the smaller properties in the Hyder district has been in progress during the year, and as a result several large groups of claims have been formed which, according to the present plans, will be explored by companies that have adequate financial backing to carry on exploration work on the scale necessary to determine the real mining possibilities of the ground.

A little silver-lead ore is mined on Prince of Wales Island near Chomly, and it was rumored that a strong company had recently. reexamined several of the old lead claims in the region a short distance east of Wrangell. Prospecting on the property of the Inspiration Point Mining Co. between Skagway and the international boundary has been carried on during the year. Although numerous lenses and masses of silver-lead ore have been found, no body of ore of sufficient size and tenor to be mined under present conditions has yet been reported.

) In the Susitna region some work was done at the ruby-silver prospect known as the Mint mine, about 9 miles east of Chulitna station on the Alaska Railroad. During the year a lease and option was given on this property, and it is understood that additional machinery and supplies were taken to the property and that the new operator proposes to erect the necessary buildings to start active development as rapidly as conditions permit. 
In the Kantishna region no production of silver-lead ores was reported. The difficulties of getting the ore to some shipping point and the high cost of transportation from such a point to a smelter have discouraged the owners from trying to send out ore under present conditions. Although no production is reported, prospecting and development work have been carried on and the search for new ore bodies has been continued. There can be no doubt that if the ores now known in the Kantishna district were more favorably situated with respect to transportation they would well repay mining, but owing to their remoteness ores carrying even $\$ 50$ a ton in silver can not repay the cost of mining, handling, and getting the ore to the smelter.

\section{LEAD}

The lead produced from Alaska ores in 1926 amounted to 1,555,500 pounds, which at 8 cents a pound (the average market price for the year as determined by the Bureau of Mines) was worth $\$ 124,400$. A comparison of this production with that of earlier years is afforded by the following table.

Lead produced in Alaska, 1892-1926

\begin{tabular}{|c|c|c|c|c|c|c|c|c|}
\hline Year & Tons & Value & Year & Tons & Value & Year & Tons & Value \\
\hline \multirow[t]{2}{*}{$\begin{array}{l}1892 \\
1893 \\
1894 \\
1895 \\
1896 \\
1897 \\
1898 \\
1900 \\
1901 \\
1902\end{array}$} & \multirow[t]{2}{*}{$\begin{array}{l}30 \\
40 \\
35 \\
20 \\
30 \\
30 \\
30 \\
35 \\
40 \\
40 \\
30 \\
30\end{array}$} & \multirow[t]{2}{*}{$\begin{array}{r}\$ 2,400 \\
3,040 \\
2,310 \\
1,320 \\
1,800 \\
2,160 \\
2,240 \\
3,150 \\
3,440 \\
3,440 \\
2,460 \\
2,520\end{array}$} & \multirow[t]{2}{*}{\begin{tabular}{|l}
1904 \\
1905 \\
1906 \\
1907 \\
1908 \\
1909 \\
1910 \\
1911 \\
1912 \\
1913 \\
1914
\end{tabular}} & \multirow[t]{2}{*}{$\begin{array}{r}30 \\
30 \\
30 \\
30 \\
40 \\
69 \\
75 \\
51 \\
45 \\
6 \\
28 \\
437\end{array}$} & \multirow[t]{2}{*}{$\begin{array}{r}\$ 2,580 \\
2,620 \\
3,420 \\
3,180 \\
3,360 \\
5,934 \\
6,600 \\
4,590 \\
4,050 \\
528 \\
1,344 \\
41,118\end{array}$} & \multirow[t]{2}{*}{$\begin{array}{l}1916 \\
1917 \\
1918 \\
1919 \\
1920 \\
1921 \\
1922 \\
1923 \\
1924 \\
1925\end{array}$} & $\begin{array}{l}820 \\
852 \\
564 \\
687 \\
875 \\
759 \\
377 \\
410 \\
631 \\
789 \\
778 \\
\end{array}$ & $\begin{array}{r}\$ 113,160 \\
146,584 \\
80,088 \\
72,822 \\
140,000 \\
68,279 \\
41,477 \\
57,400 \\
100,899 \\
140,571 \\
124,400\end{array}$ \\
\hline & & & & & & & 8,803 & $1,195,000$ \\
\hline
\end{tabular}

By far the largest part of the lead was recovered in connection. with the mining of the gold ores at the Alaska Juneau mine, in southeastern Alaska. According to the published reports of the company, it produced $1,300,915$ pounds of lead. This represents a recovery of about three-quarters of a pound of lead from each ton of ore milled. The remainder of the lead produced came principally from the silver-lead ores of the Hyder district. Lead is practically absent from the ores mined by the Kennecott Copper Corporation and the companies associated with it.

The statements relating to the silver-lead ores made in the preceding section on silver also give all the data available regarding the activities in lead mining in 1926. None of these deposits contain enough lead to be developed for their lead content alone. Although 
several of these lead-silver deposits that are now undeveloped appear to be nearly high enough in their combined lead, silver, and gold content to be mined at a profit, there does not seem to be any indication that in the near future any considerable increase in the production of lead is to be looked for except as a result of increased mining in the Hyder district and the increased milling of the gold ores of the Alaska Juneau mine.

\section{PLATINUM METALS}

Platinum is one of a group of several metals which, because they are closely related in their physical and chemical characters, are often not differentiated by name and are not even identified specifically in the usual forms of assay or analysis but are spoken of as the platinum metals. Palladium is one of the metals of this group. Practically all the platinum metals that are recovered from lodes in Alaska are palladium and lesser amounts of platinum, and they come from a single mine. Platinum metals whose bedrock source is unknown are found in placer deposits in a number of widely separated localities. They occur generally in amounts and particles so small that they escape notice or are not worth recovering.

The only lode mine from which platinum metals were produced in Alaska in 1926 is the Saltchuck mine of the Alaska Palladium Co. on Kasaan Peninsula, Prince of Wales Island, about 30 miles west of Ketchikan. The ore from this mine, which was formerly worked for its copper content, is valuable principally for its palladium, but it contains also other platinum metals and considerable gold and silver. According to the published report of the Department of Commerce, 3,566 ounces of palladium, valued at $\$ 273,938$, was shipped from Alaska in 1926. ${ }^{11}$ The average value of this metal was therefore $\$ 76.82$ an ounce, which represents a falling off of more than $\$ 6$ an ounce from the value in 1925 and was apparently too low to malse the recovery profitable. As a result, late in September the mine was reported to have discontinued operations, probably to await better market conditions.

Recovery of platinum metals from the placers was very small in 1926, and so far as known not more than 6 ounces of crude metal was sold. This was equivalent to about 5 fine ounces, which at the average price of platinum for the year was worth about $\$ 550$. Practically all of this platinum came as usual from placers in the vicinity of Dime Creek, in the eastern part of Seward Peninsula. Although this is all the placer platinum that is known to have been sold, it is

«U. S. Dept. Commerce Monthly summary of foreign commerce of the United States, December, 1926, pt. 2, p. 96, 1927. 
probable that more may have been produced. In fact, certain of the gold-placer reports indicate that platinum was noted in the clean-ups at a number of camps, though they do not state that it was separated from the gold and do not give any clue as to the amount. From these, reports and those made in earlier years, however, it is known that some platinum has been found in placer deposits on Slate Creek, in the Chistochina district, Copper River region; on Granite Creek, in the Ruby district; on Metal Creek, in the Kenai region; on several streams in the Marshall district near the mouth of the Yukon; on Boob and Chowchow Creeks, in the Tolstoi and Goodnews Bay district; on streams in the Cache Creek district, in the southwestern part of the Susitna Valley; and in some of the beach gravel on Kodiak Island. This widespread distribution and high value makes it well worth an operator's time to keep a close watch for platinum metals in the clean-ups from gold-placer mining operations. It is certain, however, that no extensive placer deposits have yet been dis covered in Alaska which are rich enough to pay for mining for the platinum content alone.

\section{TIN}

Stream tin, or cassiterite, has been found in the sluice boxes of placer-mining operations in several places in Alaska. Tin minerals have also been found in the veins and in the mineralized country rock in the Port Clarence or York region of Seward Peninsula. Tin metals were recovered in 1926 only from a placer deposit in Goodwin Gulch, in the Port Clarence region, and from placer mines at Tofty, in the Tanana region, where the recovery of tin is incidental to gold production. Some of the tin ore produced was shipped to Singapore for treatment, but part was held for ship ment to the smelter later.

The production of cassiterite in 1926 was 12.85 tons which contained an average of 62 per cent of metallic tin and was therefore equivalent to approximately 8 tons of metallic tin. The average price of metallic tin for the year, as computed by the Bureau of Mines, was 65.3 cents a pound, so that the value of the total Alaskan production was $\$ 10,400$.

As is shown by the accompanying table, the amount of tin ore on metallic tin was only a little more than half the amount produced in 1925, but as the average price in 1926 was more than 7 cents a pound higher than in 1925 the discrepancy in value was not so great. The increased price of tin is stimulating interest again in some of the deposits in western Seward Peninsula, and plans were under consideration late in 1926 which may lead to a revival of development in that district in the not distant future. 
Tin produced in Alaska, 1902-1926

\begin{tabular}{|c|c|c|c|c|c|c|c|}
\hline Year & $\begin{array}{c}\text { Ore } \\
\text { (tons) }\end{array}$ & $\begin{array}{l}\text { Metal } \\
\text { (tons) }\end{array}$ & Value & Year & $\begin{array}{c}\text { Ore } \\
\text { (tons) }\end{array}$ & $\begin{array}{l}\text { Metal } \\
\text { (tons) }\end{array}$ & Vatue. \\
\hline \multirow[t]{2}{*}{$\begin{array}{l}1902 \\
1903 \\
1904 \\
1905 \\
1906 \\
1907 \ldots 1 \\
1908 \\
1909 \\
1910 \\
1911 \\
1912 \\
1913 \\
1914\end{array}$} & \multirow[t]{2}{*}{$\begin{array}{l}25 \\
42 \\
23 \\
10 \\
57 \\
37.5 \\
42.5 \\
19 \\
16.5 \\
92.5 \\
194 \\
98 \\
157.5 \\
167\end{array}$} & \multirow[t]{2}{*}{$\begin{array}{r}15 \\
25 \\
14 \\
6 \\
34 \\
22 \\
25 \\
11 \\
10 \\
61 \\
130 \\
50 \\
104 \\
102\end{array}$} & \multirow[t]{2}{*}{$\begin{array}{r}\$ 8,000 \\
14,000 \\
8,000 \\
4,000 \\
38,640 \\
16,752 \\
15,180 \\
7,638 \\
8,335 \\
52,798 \\
119,600 \\
44,103 \\
66,560 \\
78,846\end{array}$} & \multirow[t]{2}{*}{$\begin{array}{l}1916 \\
1917 \\
1918 \\
1919 \\
1920 \\
1921 \\
1922 \\
1923 \\
1924 \\
1925 \\
1926\end{array}$} & $\begin{array}{l}232 \\
171 \\
104.5 \\
86 \\
26 \\
7 \\
2.3 \\
3 \\
11 \\
22.2 \\
12.85\end{array}$ & $\begin{array}{r}139 \\
100 \\
68 \\
56 \\
16 \\
4 \\
1.4 \\
1.9 \\
7 \\
13.8 \\
8\end{array}$ & $\begin{array}{r}\$ 121,000 \\
123,300 \\
118,000 \\
73,400 \\
16,112 \\
2,400 \\
912 \\
1,623 \\
7,028 \\
15,980 \\
10,400\end{array}$ \\
\hline & & & & & $1,658.35$ & $1,024.1$ & 972,600 \\
\hline
\end{tabular}

\section{QUICKSILVER}

Three small companies were engaged in prospecting and operating quicksilver deposits in Alaska in 1926. All of them were located in the lower part of the Kuskokwim River Valley, near Napamute and somewhat farther upstream. The operators were E. W. Parks, at the Alice and Bessie prospects; G. C. Bettles, on the Cinnabar Chief and other prospects of the Kuskokwim Mercury Co.; and Fuller \& Willis, on their claims. Altogether not more than 50 tons of ore was produced and of this only a part was retorted. From the ore that was retorted about $1 \frac{1}{2}$ per cent of metallic mercury was recovered, so that the total amount of metallic mercury produced was only a few flasks. The total value of this quicksilver, which was computed as worth $\$ 83$ a flask of 75 pounds, is included with other miscellaneous mineral products in the table on page 50 .

The general inaccessibility of the region and the high cost and the difficulty of obtaining all supplies and equipment make it impossible at this time to work profitably in this region any except rich streaks of ore. It is understood that development work on the properties of the Kuskokwim Mercury Co. failed to uncover ore of sufficiently high grade to encourage continuance of operations, and the company consequently suspended work there in August.

\section{COAL}

In general the Alaska coal-mining industry showed little change in 1926 from the conditions that prevailed in 1925. It is true that a few thousand tons more coal was produced during 1926, but the industry is still very small. Practically all the production came from three mines in the Matanuska field and one in the Healy River field, and none of these produced as much as an average of 200 tons of coal a day. The failure of the industry to increase more rapidly is doubtless due to many causes, but one of them has been that development 
of the mines was originally started by individuals or companies with scanty financial resources and little technical experience. This handicap is gradually being overcome, and during the year several properties were put into much better condition in regard to both equipment and mining methods, so that in the future they should be able to produce a cleaner, better product more efficiently and less expensively.

Although a movement of this sort is therefore predicted with considerable assurance, a notable increase in production can not be foreseen until a larger market than is at present supplied by these mines is developed. From the data in the following table it will be noted that the entire domestic production of coal in Alaska together with all the coal imported from the States or from foreign countriesthat is, the consumption of coal in Alaska in 1926-amounted to only about 157,000 tons. It is evident, therefore, that under present conditions there is only a small market in Alaska for coal. Even if this entire quantity were supplied by domestic mines it would mean an increase over the present production of coal of only about 70,000 tons, or about 80 per cent. Obviously not all of this market can be supplied from the present operating mines along the Alaska Railroad without meeting competition from some of the coal mines in British Columbia and the Northwestern States.

Coal produced and consumed in Alaska, 1880-1926

\begin{tabular}{|c|c|c|c|c|c|}
\hline \multirow{2}{*}{ Year } & \multicolumn{2}{|c|}{$\begin{array}{l}\text { Produced in Alaska, } \\
\text { chiefly subbitumi- } \\
\text { nous and lignite }\end{array}$} & \multirow{2}{*}{$\begin{array}{c}\text { Imported } \\
\text { from States, } \\
\text { chiefly bi- } \\
\text { tuminous } \\
\text { coal from } \\
\text { Washing- } \\
\text { ton a (short } \\
\text { tons) }\end{array}$} & \multirow{2}{*}{$\begin{array}{l}\text { Imported } \\
\text { irom foreign } \\
\text { countries, } \\
\text { chiefly bi- } \\
\text { tuminous } \\
\text { coal from } \\
\text { British } \\
\text { Columbia a } \\
\text { (short tons) }\end{array}$} & \multirow{2}{*}{$\begin{array}{c}\text { Total coal } \\
\text { consumed } \\
\text { (short tons) }\end{array}$} \\
\hline & Short tons & Value & & & \\
\hline \multirow[t]{2}{*}{$\begin{array}{l}1880-1915 \\
1916 \\
1918 \\
1920 \\
1921\end{array}$} & $\begin{array}{r}71,633 \\
12,676 \\
54,275 \\
75,816 \\
60,894 \\
61,111 \\
76,817 \\
79,275 \\
119,826 \\
99,663 \\
82,868 \\
87,300\end{array}$ & $\begin{array}{r}\$ 456,993 \\
57,412 \\
268,438 \\
413,870 \\
345,617 \\
355,668 \\
496,349 \\
430,639 \\
755,469 \\
559,980 \\
404,617 \\
459,000\end{array}$ & $\begin{array}{r}679,844 \\
44,934 \\
58,116 \\
51,520 \\
57,166 \\
38,128 \\
24,278 \\
28,457 \\
34,082 \\
40,161 \\
37,324 \\
35,620\end{array}$ & $\begin{array}{r}1,079,735 \\
53,672 \\
56,589 \\
37,986 \\
48,708 \\
45,264 \\
33,776 \\
34,251 \\
43,205 \\
41,980 \\
57,230 \\
34,254\end{array}$ & $\begin{array}{r}1,814,047 \\
111,282 \\
168,980 \\
165,322 \\
166,768 \\
144,503 \\
134,871 \\
141,983 \\
197,113 \\
181,804 \\
177,422 \\
157,174\end{array}$ \\
\hline & 882,154 & $5,004,000$ & $1,129,630$ & $1,566,650$ & $3,561,269$ \\
\hline
\end{tabular}

- Compiled from Monthly Summary of Foreign Commerce of the United States, 1905-1926, Bureau of Foreign and Domestic Commerce. No figures on imports before 1899 are available.

The use of coal in Alaska is certain to increase as the country becomes settled and large-scale operations such as mining develop. In fact, probably some of the present mines and canneries and other enterprises that are now using petroleum products as sources of power might use coal, if coal of a suitable quality were available at 
a reasonable price. That the original quality of the coal from the Alaskan mines is at least equal to that of the imported coal has been abundantly demonstrated. The preparation of the Alaskan coal for the market in the past, however, has not always been up to standard, and shipments of poorly prepared coal have lost rather than made customers and have resulted in restricting rather than broadening the market. This condition is being realized, and more care and skill are being devoted to preparing the coal properly, so that purchasers may feel confident that they will receive a reliable, uniform product.

The question of markets for Alaskan coal was carefully investigated even before the building of the Alaska Railroad was undertaken, and at that time Brooks ${ }^{12}$ prepared tables showing probable markets under the conditions that existed in 1909. According to these estimates there was even then a market for 120,000 tons of Alaskan coal a year under conditions where the coal would be practically without competition from coal from other sources; for 350,000 tons additional under conditions where the competition strongly favored Alaskan coal; and for 1,000,000 tons additional under conditions in which competition was about even. The cond:tions have not materially changed since that time, and although the figures are stated by Brooks to be little better than guesses, they do serve to indicate that when strong marketing organizations are built up and have available the necessary freighting facilities to deliver coal in quantity, a large increase in markets for Alaskan coal may be forecast.

A significant attempt to broaded the range of markets for Alaskan coal was made by the Healy River Coal Corporation in 1926, through the shipment of coal from its mine into southeastern Alaska. Although the experiment involved only a small amount of coal and was in consequence especially expensive, it was successful in acquainting many persons with the quality of the coal and in giving the management valuable experience in learning at first hand some of the problems connected with the shipment and marketing of its product.

In the preceding table the total value of the coal produced in Alaska in 1926 is stated as $\$ 459,000$. This value, however, is only approximately correct, as the selling price for much of the output could not be determined exactly and the average price paid for the large quantities purchased by the railroad was exceedingly low because of the relatively large size of the contracts. The Alaska Railroad entered into contracts during the fiscal year 1926 for 39,500 tons of all kinds of coal at an average price of $\$ 4.21$ a ton for mine

\footnotetext{
1910.

12 Brooks, A. H., Alaska coal and its utilization: U. S. Geol. Survey Bull. 442, p. 94,
} 
run and $\$ 3.80$ a ton for steam sizes. The prices for smaller lots, however, which took more than half of the output, averaged much higher, so that the weighted average price of all the coal sold was approximately $\$ 5.25$ a ton. This figure is not far from the average price of all the coal produced during the period prior to 1926 covered by the records shown in the foregoing table, namely, $\$ 5.72$ a ton. It is somewhat higher than the average price used in 1925 , which was $\$ 4.88$ a ton. The greater production in 1926, together with the assumed higher price per ton, indicates a total value of the output of coal in that year about $\$ 54,000$ greater than in 1925 .

The three main producing mines in the Matanuska field are the Evan Jones, Alaska Matanuska, and Premier. The Evan Jones mine is at Jonesville, on the Eska spur of the Chickaloon branch of the Alaska Railroad. Mining there was active until late in August, when the mine was closed down for the rest of the year. In the Moose Creek valley the reconstruction of the railroad spur, which had been badly damaged by the freshets of the preceding fall, somewhat hampered the shipment of coal early in the season, and later new construction and the installation of machinery at the Alaska Matanuska mine kept the production from that property at a low level until September. From that time until the end of the year the average monthly production from the mine exceeded the entire production for the first eight months and clearly indicated that the new installations had greatly increased the efficiency of the plant. The production of the Premier mine was maintained at a rather high rate for mines in this field until August, when it fell off markedly for several months. A new contract with the railroad for coal, however, revived work at this mine in December, so that during that month the production was far above the average. A little coal was produced late in the year from the Rawson property, on Moose Creek, where prospecting has been in progress for several years. The only other place in the Matanuska Valley where coal prospecting was reported was on Coal Creek, a few miles south of Chickaloon. Not more than three men were employed on this property during any month, and the work was of a prospecting character, though a small amount of coal was produced which was used on the ground for local purposes.

In the Healy River field the Suntrana mine of the Healy River Coal Corporation, on a spur about 4 miles from the main line of the Alaska Railroad, was in continuous operation throughout the year. During the early part of the summer the production of the mine was reduced while necessary changes and reconstruction of the plant were in progress. On the completion of this work the output improved considerably both in quality and amount, and in December more was 
produced than in any other month of the year. As already noted, shipments from this mine were made to several points in southeastern Alaska, and contracts entered into with one of the large mining companies in the Fairbanks district have resulted in considerably broadening the market for this coal. The mine is now well lequipped with thoroughly modern machinery for both surface and underground operations, and it appears to have established satisfactory distributing facilities so that its present output is readily marketed.

Some 5 miles farther up Healy River the coal property of R. F. Roth has received considerable attention during the year. It is understood that arrangements have practically been completed whereby ) a spur from the Suntrana branch of the railroad is to be constructed to the property as early as practicable in 1927. This construction will be relatively difficult and expensive, because for much of the distance the valley floor is too narrow to afford a satisfactory grade for a railroad without much cribbing. The owners expect that a good deal of coal can be recovered by surface methods of mining, so that little preparatory work on the coal bed itself has been done.

A small amount of coal was mined during the year on Kuk Inlet, some 20 miles south of Wainwright, in northern Alaska. This coal is dug from the face of a cliff by Eskimos, sacked and carried to Wainwright in their skin boats, and used locally by the white traders and natives. It is a considerable asset in a region where even brush is practically absent, but the quality is so poor because of the conditions under which it is mined that those who can do so prefer to burn coal that is imported and costs about three times as much.

A small amount of coal is also said to have been mined on Chicago , Creek, in the northeastern part of Seward Peninsula. This is the deposit to which it was proposed to extend the tramway from Nome in the hope of affording the near-by placer miners fuel at a lower cost than was being currently paid for coal shipped in from the States. The coal is not of such quality, however, as to give promise of having more than local value except in the less accessible parts of the peninsula. A small quantity of the coal is said to be used by I the placer miners, especially those in the vicinity of Candle.

No productive coal mining has been reported to have been in progress in other parts of Alaska in 1926. In the Bering River field some additional investigations have been in progress by commercial interests, and it is currently reported that steps are under way looking to the development of this field in the near future if satisfactory arrangements can be made for developing several of the properties coincidently. As was noted in the report on the mineral industry for 1925 , there have been rumors that the Alaska 
Anthracite Railroad had been taken over by a new company and was to be equipped for handling coal. No active steps to this end, however, have been reported.

\section{PETROLEUM}

The only petroleum produced in Alaska comes from the wells of the Chilkat Oil Co. in the Katalla field. At this place the company obtains oil from a number of shallow wells, few of which are more, than a thousand feet deep. A small refinery is operated by the company, and the products-gasoline and distillate-find a ready market near at hand, especially at Cordova. As this was the only petroleum produced in Alaska in 1926, its value has been included with that of the miscellaneous mineral products in the table on page 50 .

There is a market in Alaska for large quantities of petroleum products, but owing to the small domestic production most of the demand is supplied by shipments from the States proper. The following table shows the amount of the different kinds of petroleum products that were shipped into Alaska during 1926 as well as for the preceding years. The most notable feature of this table is the constant increase since the war in the amount of gasoline and related products used. This increase reflects the growing use of power in fishing boats and other water craft, in the canneries, in many mining developments, and in the operation of means of transportation, such as the Copper River \& Northwestern Railway, and automobiles.

Petroleum products shipped to Alaska from other parts of the United States, 1905-1926 in gallons ${ }^{a}$

\begin{tabular}{|c|c|c|c|c|}
\hline Year & $\begin{array}{l}\text { Heavy oils, } \\
\text { jncluding } \\
\text { crude oil, gas } \\
\text { oil, residuum, } \\
\text { etc. }\end{array}$ & $\begin{array}{c}\text { Gasoline, } \\
\text { including all } \\
\text { lighter } \\
\text { products of } \\
\text { distillation }\end{array}$ & $\underset{\text { oil }}{\text { Illuminating }}$ & $\begin{array}{c}\text { Lubricating } \\
\text { oil }\end{array}$ \\
\hline \multirow[t]{2}{*}{$\begin{array}{l}1905 \\
1906 \\
1907 \\
1908\end{array}$} & $\begin{array}{r}2,715,974 \\
2,688,940 \\
9,104,300 \\
11,891,375 \\
14,119,102 \\
19,143,091 \\
20,878,843 \\
15,523,555 \\
15,682,412 \\
18,601,384 \\
16,910,012 \\
23,555,811 \\
23,971,114 \\
24,379,566 \\
18,784,013 \\
21,981,569 \\
9,209,102 \\
15,441,542 \\
12,285,808 \\
14,412,120 \\
16,270,746 \\
14,000,664\end{array}$ & $\begin{array}{r}713,496 \\
580,978 \\
636,881 \\
939,424 \\
746,930 \\
788,154 \\
1,238,865 \\
2,736,739 \\
1,735,658 \\
2,878,723 \\
2,413,962 \\
2,844,801 \\
3,256,870 \\
1,086,852 \\
1,007,073 \\
1,764,302 \\
1,403,683 \\
1,436,050 \\
4,882,015 \\
5,554,859 \\
6,993,560 \\
5,069,584\end{array}$ & $\begin{array}{r}627,391 \\
568,033 \\
510,145 \\
566,598 \\
531,727 \\
620,972 \\
423,750 \\
672,176 \\
661,656 \\
731,146 \\
513,075 \\
732,369 \\
750,238 \\
382,186 \\
3,515,746 \\
887,942 \\
2,021,033 \\
2,095,675 \\
473,826 \\
566,431 \\
562,844 \\
328,615\end{array}$ & $\begin{array}{r}83,319 \\
83,992 \\
100,145 \\
94,542 \\
85,687 \\
104,512 \\
100,141 \\
154,565 \\
150,918 \\
191,876 \\
271,981 \\
373,046 \\
465,693 \\
362,413 \\
977,703 \\
412,107 \\
232,784 \\
345,400 \\
454,090 \\
506,364 \\
580,321 \\
730,924\end{array}$ \\
\hline & $341,551,043$ & $50,709,399$ & $18,743,574$ & $6,862,523$ \\
\hline
\end{tabular}

a Compiled from Monthly Summary of Foreign Commerce of the United States, 1905 to 1926, Bureau of Foreign and Domestic Commerce. 
Among the notable oil developments of the year were prospecting in the Yakataga oil field and the abandonment of drilling operations on the Pearl Creek dome, in the Alaska Peninsula. Heavy storms in the fall of 1925 interrupted drilling operations in the Yakataga field and resulted in cessation of work there until June, 1926. In that month additional equipment with an experienced crew of men was sent by the General Petroleum Co. to the claims near Johnson Creek. Active work was at once undertaken, so that within a short time drilling was in progress. Some difficulty with salt water was encountered near the surface, but after this was cased off drilling proceeded uninterruptedly until Aungust, when some time was lost, owing to casing troubles. Drilling was later resumed, and appears to have continued during the fall and early winter as rapidly as water conditions permitted. The property has not been visited lately by any member of the Geological Survey, but from current reports it appears that by the end of the year the well had been drilled to a depth of more than 500 feet with a Star rig. The hole is said to have been started with a $151 / 2$-inch casing, which was carried to a depth of 61 feet; from that depth to 240 feet a 12-inch casing was used, and below that depth to at least 300 feet an 8-inch casing was used. A considerable flow of gas was said to have been cut at a depth of 240 feet, and signs of petroleum were reported at a number of places between 200 and 300 feet, the depths at which the latest detailed data that have come to the attention of the Geological Survey were obtained.

The drilling operations that had been carried on by the Standard Oil Co. of California on the Pearl Creek dome since 1923 were definitely discontinued early in 1926, after the hole had reached a depth of 5,034 feet. In commenting on this well, which was known as the Lee No. 1 , the company states: ${ }^{13}$

It was drilled with cable tools and a gas engine to a depth of 5,034 feet, took three years to drill, and is dry in the sense that it proved wholly unproductive of petroleum; it turned out to be what in oil-field vernacular is termed a "duster."

Some 17 miles inland, across two mountain ranges and several miles of swamp land, was the location that had been selected for drilling operations. 1 For six months road building and transportation of equipment to this point occupied the expedition. In March, 1923, the well was spudded in. Three years later, last month, it was abandoned. It was well situated in the area and constituted a full test of the formation, in the opinion of the company geologists.

Aside from the fact that no oil-bearing stratum was encountered, the outstanding feature of this wildcat well was the amount of hole made in hard formations. The first 1,600 feet was through extremely hard sandstone and conglomerate that equaled it in toughness. Very often not more than a foot of hole a day was made during this stage of drilling. Deeper wells than this have

1s Standard Oil Bulletin, April, 1926, pp. 6-16.

$6097^{\circ}-29-4$ 
been drilled and harder formations encountered, but it is believed that in all the annals of well drilling there is not another instance where bits were called upon to penetrate to the depths attained through formations of equal hardness.

Although, as stated by the company's geologists, this well probably gave a fair and conclusive test of the part of the Pearl Creek dome in which it was drilled, it should not be considered at all conclusive in determining the petroleum possibilities in other parts of the peninsula, because in other places the probable oil-bearing beds are believed to lie many thousand feet nearer the surface. For instance, W. R. Smith ${ }^{14}$ has stated that in the vicinity of Wide Bay the strata at the surface are essentially the same as those encountered in the vicinity of the Pearl Creek dome at a depth of not less than 4,000 feet.

Although no other drilling is in progress on the Alaska Peninsula, as the Associated Oil Co., which drilled a hole to a depth of more than 3,000 feet on the Pearl Creek dome, had also discontinued work, there were a number of places where persons were reported to be considering further work if their applications for prospecting permits were approved. These projects, however, can scarcely be expected to reach the stage of actual drilling before another year.

Drilling for oil in the vicinity of Chickaloon was carried on during the summer. Considerable difficulty was experienced in getting through the unconsolidated surface deposits, because of the large number and size of the boulders. It is understood that drilling operations were suspended about November 1 , because casing of the proper size was not available. The hole at that time is said to have been carried to a depth of about 190 feet. The main basis for a selection of this area for testing appears to have been the reported occurrence of oil in one of the test holes drilled by the Government some years ago in connection with its development of the Chickaloon coal mine. The geology in the vicinity of the test well, however, is not such as to appear favorable for the production of petroleum.

The search for oil in Naval Petroleum Reserve No. 4, in northern Alaska, was continued in 1926 by members of the Geological Survey. A party consisting of a geologist and topographer with the necessary camp assistants left Nenana in February. and went with dog teams $\boldsymbol{r}$ to Kotzebue, and thence into the region adjacent to and included in the western and northwestern part of the reserve. Geologic and topographic mapping was carried on throughout the unsurveyed area with the aim of finding any indications of petroleum that might occur and determining the area in which oil pools might be expected. A short account of the principal features and results of this work is given in a separate chapter of this report.

\footnotetext{
${ }^{14}$ Smith, W. R., Geology and oil developments of the Cold Bay district; U. S. Geol. Survey Bull. 783, pp. 63-87, 1926.
} 


\section{MISCELLANEOUS MINERAL PRODUCTS}

Many other mineral products have been exploited in Alaska. The list of these minerals is long, including such metals as antimony, arsenic, bismuth, chromium, iron, molybdenum, nickel, and tungsten and such nonmetallic minerals as asbestos, barite, clay, garnet, graphite, gypsum, lime, marble, mica, stone, and sulphur. So far as reported to the Geological Survey none of these mineral products were produced and sold in 1926 with the exception of marble, though doubtless some of them were produced in the course of other mining operations. Most of the marble produced came from quarries at Tokeen, on Marble Island, near the north end of Prince of Wales Island. These quarries are owned and operated by the Vermont Marble Co., and the quarrying operations at this place were carried on in somewhat greater volume than heretofore. In the past several marble quarries were in operation in southeastern Alaska, and it is strange that deposits so favorably situated to ocean transportation as many in the places where marble is known have not been profitably developed commercially. According to Burchard, ${ }^{15}$ many types of marble occur in these deposits, some even approaching statuary grade. A few properties have been somewhat exploited, but considerable areas of marble are known in which no development work has been done.

An interesting new mineral development in southeastern Alaska is the search for suitable deposits of sulphur required for the manufacture of paper pulp. The increasing development of the forest products of southeastern Alaska, especially for making paper, is certain to call for considerable quantities of sulphur. The extensive pyrite deposits which are found at many places near the borders of the large granitic intrusions of the Coast Range give promise of affording a near-by source sufficient to supply almost any quantity that might be reasonably required for this purpose. It may also be profitable for a company needing pyritic ore for sulphur to examine into the possibility of obtaining concentrates from the mills of lode companies, even if it were necessary to obtain them with the provision that the material remaining after roasting should be returned to the original producing company. This would be somewhat analogous to the method in vogue some years ago, when the sulphur of the copper-bearing Spanish pyrites ores was utilized by Ipaper makers in the eastern United States and the "cinder" or residue, containing copper and iron, turned back to the seller for smelting.

${ }^{15}$ Burchard, E. F., Marble resources of southeastern Alaska : U. S. Geol. Survey Bull. 682, 118 pp., 1920. 
In many of the tables accompanying this report a group of miscellaneous mineral products has been shown. This group includes not only the products mentioned in the foregoing paragraphs under this heading but also all those products that are produced in quantities so small that to list them separately would disclose the production of individual operators. Among the mineral commodities that are included in this miscellaneous group in the tables are petroleum, stone, marble, and quicksilver. In the accompanying table is shown the value of the output of these minerals in 1926 and preceding years. At first sight the table seems to indicate a marked decrease from 1925 . This is not really the case, however, for the figure for 1925 includes the production of lode platinum metals, which have been shown in a separate table for 1926. If the production of those metals, given on page 39 as about $\$ 274,000$, had been included in this miscellaneous group for 1926, the total would have been essentially the same as that given for 1925 .

Value of output of miscellaneous mineral products of Alaska, including petroleum, gypsum, marble, and other products, 1901-1926

\begin{tabular}{|c|c|c|c|c|c|}
\hline Year & Value & Year & Value & Year & Value \\
\hline 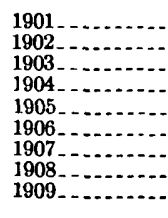 & $\begin{array}{r}\$ 500 \\
255 \\
389 \\
2,710 \\
710 \\
19,965 \\
54,512 \\
81,305 \\
86,027\end{array}$ & $\begin{array}{l}1910 \\
1911 . \\
1912 \\
1913 \\
1914 \\
1915 \\
1916 \\
1917 \\
1918\end{array}$ & $\begin{array}{l}\$ 96,408 \\
145,739 \\
165,342 \\
286,277 \\
198,767 \\
205,061 \\
326,737 \\
203,971 \\
171,452\end{array}$ & \begin{tabular}{|l}
1919 \\
1920 \\
1921 \\
1922 \\
1923 \\
1924 \\
1925 \\
1926
\end{tabular} & $\begin{array}{r}\$ 214,040 \\
372,599 \\
235,438 \\
256,296 \\
229,486 \\
348,728 \\
454,207 \\
170,000 \\
4,338,000\end{array}$ \\
\hline
\end{tabular}




\title{
ADMINISTRATIVE REPORT
}

\author{
By Philip S. Smith
}

\section{INTRODUCTION}

The work performed by the Geological Survey, like much of the other work of the Government, is reported by fiscal years. Adherence to this practice in reporting the work done by the Geological Survey in Alaska results in confusion and fails to bring out the larger aspects of the work and the real scope. Furthermore, the fiscal year for that work is really a more or less indefinite period, because most of the appropriations for the Alaskan investigations of the Geological Survey are immediately available on the passage of the act through which the money is appropriated. Thus work done during the fiscal year beginning July 1, 1926, and ended June 30, 1927 , may have been paid for from two appropriations for the same object, which ran in part concurrently. Again, several of the field projects that were in progress during the season of 1926 were started before July 1 and therefore may have been paid for from the appropriations for the fiscal year 1925-26.

In order that the character of the Alaskan work done by the Geological Survey may be better understood the following typical example of various stages in most of the field projects is given. Early in the spring steps for carrying out a project are taken. The necessary supplies and equipment are ordered, and the services that will be required are arranged for. Sometimes the geologists and engineers leave for the field as early as February, and ordinarily all of them are on the way to their field assignments in May. This early start is necessary to utilize fully all of the open season that is available and suitable for carrying on field investigations. From that time on the surveys are made uninterruptedly until the fall, when the parties are compelled to discontinue work because of the frosts that kill the forage for their pack animals or the snow that masks the rocks and country and so stops further geologic work. After the conclusion of the field work the next six to eight months is spent by the field men in the office and laboratory duties essential to completing their maps and reports and seeing them through the 
several stages of publication. These office and laboratory duties include the examination and microscopic investigation of the rocks and ore specimens that have been collected during the field work and the chemical analysis of such as require that means of determination, the identification of the fossils that have been collected, the computation of the mathematical factors involved in the mapping work, the thorough examination of any books or reports relating to the region in which the work was done or on subjects bearing on the work which is in progress, and the writing of the reports and perfecting of the maps, diagrams, and other illustrative material. Many of these steps require specialized knowledge and experience, so that no one field man will himself do all the work required but will utilize the assistance of those members of the Geological Survey who are most expert in each particular line of work. Some time is also given to correcting the manuscript and proofs of the maps and reports and to assisting in answering inquiries from correspondents and others seeking information regarding Alaskan subjects. When all these duties have been completed it is usually time for the field man to leave for another field assignment. In fact probably before the old job is completed he has begun to take active steps in preparing for the new work. In this way he may be working jointly on two projects at the same time, and an attempt to record the distribution of the time accurately between the two would not only be extremely difficult and uncertain but would yield no practical results.

The main point, which it is hoped has been explained by the foregoing description, is that the Alaskan work is done on a project basis and that to describe it on the basis of a fiscal year or on a basis of the particular appropriation from which it was paid complicates rather than clarifies the major aspects of the work. Of course all the expenditures have been accounted for in detail in such a manner as is provided for by law and regulations of the.Government and are all matters of record.

The funds used by the Geological Survey in its Alaska work are provided in two items in the general act making appropriations for the Interior Department. One of these is "for continuation of the investigation of the mineral resources of Alaska, * * *." In the act for $1925-26$ the amount of this item was $\$ 72,000$, in the act for $1926-27$ it was $\$ 50,000$, and in the act for $1927-28$ it was $\$ 60,000$. As has already been noted, each of these appropriations was available immediately on the passage of the act in which it was contained.

The other item is an allotment made from the appropriation "for the enforcement of the provisions of the acts of October 20,1914, October 2, 1917, February 25, 1920, and March 4, 1921, and other acts relating to the mining and recovery of minerals on Indian and 
public lands and naval petroleum reserves, * * *." Appropriations carried under this item are available only during the specified fiscal year. In the fiscal year 1926-27 an allotment of $\$ 19,500$ was made for the kind of work in Alaska that is described by the language of the act. The two types of work indicated by the different phraseology of the appropriation items will be described separately in the following pages and for convenience will be referred to briefly, as the mineral-resources work and the leasing work.

\section{MINERAL-RESOURCES WORK}

\section{EXPENDITURES}

Expenditures for the mineral-resources work during the fiscal year beginning July 1, 1926, from the appropriation for 1926-27 may be distributed among the following major heads:

Expenditures from funds appropriated for mineral-resources investigations in Alaska for the fiscal year 1926-27

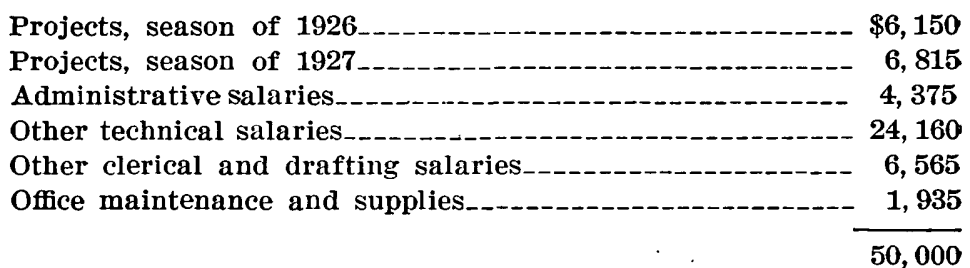

Obviously the most important branch of these investigations is the preparation of the maps and reports which make available to the public the results of these surveys. As a consequence every effort is put forth to make the work as productive as possible, and every item in the foregoing analysis of expenditure is really maintained as an cssential adjunct of that work. Thus the technical salaries are paid primarily for the field and office work attendant on these surveys. The clerical and drafting help is required to assist in preparing the manuscript for copy and in the countless details that are necessary in the conducting of the business connected with this work. However, in the items as tabulated for projects are included only the specific amounts that were actually expended in the field or were paid for equipment and supplies to be used exclusively in these projects. Furthermore, only the amount expended from the appropriation for 1926-27 is tabulated, but as already explained most of the projects included in the item for the season of 1926 were started in the previous fiscal year, and $\$ 16,735$ was put into the start of these projects from funds carried in the appropriation for 1925-26. Similarly only a beginning of the projects in the list included in the item for the season 1927 was made during the fiscal year 1926-27, and $\$ 18,485$ additional has been allotted from the appropriation for 1927-28 to complete them. These items do not include any charges 
for the technical services of the personnel assigned to these projects, which are reported on page 63 , under the heading "Other technical salaries."

\section{PRINCIPAL RESULTS OF THE YEAR}

The principal results of the field investigations have been the mapping both geologically and topographically of about 7,250 square miles of country during the year. All of this is country that had not been hitherto surveyed, except 350 square miles representing mapping in more detail in country that had hitherto been mapped on a much smaller scale on only exploratory standards. The following tabular statement may serve to indicate the amount of the various kinds of surveys that have been made in Alaska up to the present time by the Geological Survey. It should be noted that the amount is stated by field seasons and that no report is made of the field season of 1927 , because all the parties are out of communication and it is not practicable to give the precise area surveyed up to the end of the fiscal year. This, however, is offset for all practical purposes because for the field season of 1926 all of the area surveyed during that season is reported, even though the work was commenced in the earlier fiscal year. In this way the amount of work done in the fiscal year 1925-26 on projects of the 1926 field season presumably balances the amount of work that was done in the fiscal year 1926-27 on the projects of the 1927 season.

Areas surveyed by Geological Survey in Alaska, 1898-1926, in square miles

\begin{tabular}{|c|c|c|c|c|c|c|}
\hline \multirow[b]{2}{*}{ Field season } & \multicolumn{3}{|c|}{ Geologic surveys } & \multicolumn{3}{|c|}{ Topographic surveys } \\
\hline & $\begin{array}{c}\text { Explora- } \\
\text { tory (scale } \\
1: 500,000 \\
1: 625,000 \\
\text { or } \\
1: 1,000,000)\end{array}$ & $\begin{array}{l}\text { Reconnais- } \\
\text { sance (scale } \\
1: 250,000)\end{array}$ & $\begin{array}{c}\text { Detailed } \\
\text { (scale } \\
1: 62,500 \\
\text { or larger) }\end{array}$ & $\begin{array}{c}\text { Explora- } \\
\text { tory (scale } \\
1: 500,000, \\
1: 625,000, \\
\text { or } \\
1: 1,000,000)\end{array}$ & $\begin{array}{c}\text { Reconnais- } \\
\text { sance (scale } \\
1: 250,000, \\
200 \text {-foot } \\
\text { contours) }\end{array}$ & $\begin{array}{c}\text { Detailed } \\
\text { (scale } \\
1: 62,500 ; \\
25,50 \text {, or } \\
\text { 100-foot } \\
\text { contours) }\end{array}$ \\
\hline \multirow[t]{2}{*}{$1898-1925$} & $\begin{array}{r}75,500 \\
-350 \\
\end{array}$ & $\begin{array}{r}154,505 \\
7,250 \\
\end{array}$ & \begin{tabular}{r}
5,977 \\
\hdashline \\
\end{tabular} & $\begin{array}{r}55,980 \\
-350 \\
\end{array}$ & $\begin{array}{r}190,150 \\
7,250\end{array}$ & $\begin{array}{r}4,066 \\
- \\
\end{array}$ \\
\hline & 75,150 & 161,755 & 5,977 & 55,630 & 197,400 & 4,066 \\
\hline $\begin{array}{l}\text { Percentage of total area of } \\
\text { Alaska }\end{array}$ & \multicolumn{3}{|c|}{41.1} & \multicolumn{3}{|c|}{$\begin{array}{l}\circ \quad 43.5 \\
\end{array}$} \\
\hline
\end{tabular}

In this table only the net areas surveyed are listed in the appropriate columns, and there is no duplication of areas in the columns for geologic surveys or in those for topographic surveys. In other words, when an area mapped on a reconnaissance standard includes areas formerly mapped on exploratory scales, the entire area is included in the column of reconnaissance surveys, and the appropriate amount is deducted from the area previously reported as having been mapped on an exploratory scale. It is for this reason 
that a deduction is shown in the column for exploratory surveys, because, as explained above, some of that area was remapped in more detail in 1926. The necessity for doing over some areas on a more detailed scale is probably obvious and does not indicate wastefulness or poor judgment. For many areas in Alaska exploratory mapping is all that is warranted for some time. In other areas it was necessary to do the more rapid and less expensive exploratory work so as to meet urgent demands for immediate information, with the intention that in selected areas or as funds and personnel could be made - available surveys of the more detailed types would be made. Even a reconnaissance survey is entirely inadequate for many types of investigation, and unquestionably more detailed maps and reports should be undertaken in the areas that are of economic importance. The fact, therefore, that at present a little more than two-fifths of Alaska has been mapped on some scale does not tell the entire story. Much of the area now covered only by exploratory surveys should be resurveyed on a reconnaissance scale, and some of the areas mapped on a reconnaissance scale should be remapped on a detailed scale. The inadequacy of information on which to base sound business enterprise in a region where the best maps available are on a scale of 4 miles to the inch is apparent not only to engineers but to all business men. At the rate at which the work is now being conducted it will be more than half a century before maps on even exploratory or reconnaissance scales will be available for those parts of the territory that hold promise of commercial development.

During the year seven Alaska reports have been issued, as follows:

Mineral investigations in southeastern Alaska, by A. F. Buddington (Bulletin 783-B).

Geology and oil development of the Cold Bay district, by Walter R. Smith, and $\mathbf{A}$ ruby-silver prospect in Alaska, by S. R. Capps and M. N. Short (Bulletin 783-C).

The Nixon Fork country and Silver-lead prospects near Ruby, by John S. Brown (Bulletin 783-D).

Summary of recent surveys in northern Alaska, by Philip S. Smith, J. B. Mertie, jr., and W. T. Foran (Bulletin 783-E).

Mineral resources of Alaska; report on progress of investigations in 1924, by Philip S. Smith and others (Bulletin 783).

) The Iniskin-Chinitna Peninsula and the Snug Harbor district, Alaska, by Fred H. Moffit (Bulletin 789).

Geology of the upper Matanuska Valley, Alaska, by Stephen R. Capps, with a

section on the igneous rocks, by J. B. Mertie, jr. (Bulletin 791).

Thirteen reports which have been completed by the authors and approved for editing or printing are now in various stages of publication. These reports are as follows:

The Upper Cretaceous floras of Alaska, by Arthur Hollick, with a description of the Upper Cretaceous plant-bearing beds, by G. C. Martin. 
Mineral industry of Alaska in 1925 and administrative report, 1925-26, by Fred H. Moffit (Bulletin 792-A).

Geology of the Knik-Matanuska district, by K. K. Landes (Bulletin 792-B). The Toklat-Tonzona region, by $\mathbf{S}$. $\mathbf{R}$. Capps (Bulletin 792-C).

Geologic investigations in northern Alaska (1925), by Philip $\mathbf{S}$. Smith (Bulletin 792-C).

Mineral industry of Alaska in 1926, and Administrative report, 1926-27, by Philip S. Smith (Bulletin 797-A).

The Skwentna region, by S. R. Capps (Bulletin 797-B).

A preliminary report on the Sheenjek River district, by J. B. Mertie, jr. (Bulletin 797-C).

Surveys in northwestern Alaska in 1926, by Philip S. Smith (Bulletin 797-D).

Geology and mineral deposits of southeastern Alaska, by A. F. Buddington and Theodore Chapin (Bulletin -).

Geology of Hyder and vicinity, with a reconnaissance of Chickamin River, southeastern Alaska, by A. F. Buddington (Bulletin -).

Six reports, listed below, are in active course of preparation by the authors:

Northwestern Alaska, by Philip S. Smith and J. B. Mertie, jr.

Airplane mapping in southeastern Alaska in 1926, by F. H. Moffit and R. H. Sargent.

Outline of the igneous geology of Alaska, by J. B. Mertie, jr.

The geology and mineral resources of the Chignik district, Alaska, by R. S. Knappen.

The Tertiary flora of Alaska, by Arthur Hollick.

Geology of the upper Yukon Valley, by J. B. Mertie, jr.

Several other reports are in course of preparation by their authors, but additional field work will be required before their completion, and the time of publication is remote. They are, therefore, not listed above.

\section{PROJECTS FOR THE SEASON OF 1926}

The projects carried on during the season of 1926 were distributed / through all parts of the Territory and dealt with a wide range of subjects connected with the development of the mineral resources of Alaska. The following table gives in summary form the regions in which the work was done and the expenditures for these projects:

Approximate cost and distribution of work by geographic divisions for the field season 1926

\begin{tabular}{|c|c|c|c|c|c|}
\hline \multirow{2}{*}{ Region or work } & \multicolumn{2}{|c|}{$\underset{1925-26}{\text { Appropriation for }}$} & \multicolumn{2}{|c|}{$\begin{array}{l}\text { Appropriation for } \\
1926-27\end{array}$} & \multirow{2}{*}{ Total } \\
\hline & Expenses & Salaries & Expenses & Salaries & \\
\hline \multirow[t]{2}{*}{$\begin{array}{l}\text { Southeastern Alaska } \\
\text { Copper River } \\
\text { Alaska Range } \\
\text { Yukon } \\
\text { Northern Ajaska. } \\
\text { General } \\
\text { Mineral resourcesa }\end{array}$} & $\begin{array}{r}\$ 450 \\
4,300 \\
4,115 \\
7,870 \\
\hdashline-2 .\end{array}$ & $\begin{array}{r}\$ 575 \\
1,085 \\
800 \\
3,620 \\
\hdashline\end{array}$ & $\begin{array}{r}\$ 1,140 \\
210 \\
1,085 \\
1,815 \\
1,400 \\
500\end{array}$ & $\begin{array}{r}\$ 3,815 \\
640 \\
6,395 \\
3,150 \\
3,840 \\
1,340 \\
a 1,925\end{array}$ & $\begin{array}{r}\$ 5,980 \\
850 \\
12,865 \\
9,880 \\
16,730 \\
1,840 \\
1,925\end{array}$ \\
\hline & 16,735 & 6,080 & 6,150 & 21,105 & 50,070 \\
\hline
\end{tabular}

- Includes $\$ 1,475$ for clerical salaries. 
The work in southeastern Alaska was all related to the airplane mapping of that region that was carried on by the Navy Department in response to a request from the Geological Survey. The items listed in the foregoing table do not include $\$ 7,000$ that was turned over to the Navy from an earlier appropriation for the necessary photographic supplies, nor does it include any of the expenditures made by the Navy. It includes only the salary and expenses of the Geological Survey representative, $\mathbf{R}$. H. Sargent, topographer, who accompanied the expedition, and certain of the office expenses and salaries connected with printing the films and preparing them for use in the map compilations that are to be made from the pictures. This work was continued during the entire winter, and an additional allotment for it was made from the funds for 1927 projects, as noted on a later page. The Navy expedition accomplished noteworthy results, and the whole-hearted cooperation of the many Government organizations that made this work a success is gratefully acknowledged.

The work in the Copper River region was of a general character and was directed principally toward the determination of the conditions under which the copper deposits of that area occur. This work was done by Fred $\mathrm{H}$. Moffit in the course of the general investigations of the mineral resources of Alaska.

Combined geologic and topographic surveys were made on the eastern flanks of the Alaska Range in the vicinity of Skwentna River by a party in charge of S. R. Capps, geologist, and K. W. Trimble, topographer. Through cooperation with the Alaska Railroad the transportation of the party from Anchorage to the mouth of Skwentna River was facilitated, and through the generosity of William N. Beach, who supplied an extensive pack train at a merely nominal charge, the cost of the work was reduced about $\$ 4,000$. A description of this work and a statement of geologic results, together with a map of the region, form a separate chapter of this report. No new areas of mineralization were discovered, but the geologic observations brought to light many data on the history of the region, and the topographic work affords reconnaissance maps of over a 1,000 square miles.

North of Yukon River, in the unmapped valley of Sheenjek River, a combined geologic and topographic party in charge of $J$. B. Mertie, jr., geologist, with J. O. Kilmartin, topographer, did reconnaissance mapping. Unfortunately one of the camp assistants was 'injured in the course of the work, so that it was necessary to cut the season short and return to Fort Yukon for medical attention. The 
loss of part of the usual working season was the result of sending a party with so scanty a personnel that when an accident occurred which necessitated sending someone out with the injured man there were too few left to conduct the work. In spite of the early close of this work approximately 1,200 square miles of hitherto unsurveyed country was mapped, and the principal geologic features were determined. The party, however, was just getting into the areas that were geologically most significant when the work was discontinued. A report of this work, by Mr. Mertie, forms a separate section of this volume.

The work in northwestern Alaska was a continuation of the surveys; first started in 1923, principally at the request of the Navy Department and at that department's expense, to determine the possibilities of petroleum in Naval Petroleum Reserve No. 4. Although the Navy Department decided not to allot any more money to that work for the season of 1926 there were many points concerning the geology of the reserve and contiguous area that the Geological Survey felt required further examination before its task of exploring the region could be considered reasonably complete. A party consisting of Philip S. Smith, geologist, and Gerald FitzGerald, topographer, left for this region in February, 1926, and continued work there until late in August, when the last vessels that could be counted on for transportation left for the season. As a result of this work the geology and topography of an area of approximately 5,000 square miles were surveyed. It may be significant to point out that although this project cost more than any of the others that were undertaken in the season of 1926 and was in a most inaccessible region where costs might be expected to be especially high, the extremely long season that was utilized and the consequently greater area covered made the unit cost of this work extremely low.

The work here grouped under general investigations includes a number of special studies. Among these may be mentioned the work done by F. H. Moffit relating to the general situation of the mineral industry in Alaska, with a view to assisting in keeping track of the new work in progress and determining those places in which further surveys would be most likely to bring productive results. ? Paleobotanic studies by C. A. Hollick of certain plant collections from northern areas were made with the aim of assisting the geologists in the correlation of coal-bearing beds in that region. Studies were made by J. B. Mertie, jr., of the igneous rocks which are in many regions the source of mineralization that has produced deposits of commercial value. In addition Mr. Mertie spent considerable 
time in the revision of his manuscript covering earlier work in northern Alaska. Considerable service was rendered without reimbursement from Alaskan funds by T. W. Stanton, G. H. Girty, J. B. Reeside, jr., and Edwin Kirk, paleontologists of the Geological Survey, who examined the fossil collections made in the course of the different surveys and prepared reports of their determinations. The chemists of the geologic branch also assisted, on request, in identifying and testing certain rocks and minerals. The map editors of the topographic branch rendered assistance in carefully scrutinizing the maps that were in course of preparation.

The collection of data on the production of minerals and ores in Alaska is an annual duty that is performed by the Alaskan branch. Although no direct field expenditure is incurred for this work, all the field geologists and engineers of the Geological Survey who are engaged in Alaskan work contribute much material as a by-product, that would require the expenditure of several thousand dollars if the same data were collected as a separate investigation. As it is, the only expense of this work is part of the time of a clerk and about a month of the time of the chief Alaskan geologist. The result of this annual canvass of the mineral industry is a preliminary estimate of the production issued on January 1 , for the preceding calendar year, and a more complete report issued as soon thereafter as final figures for the mineral production are available. The final report for 1926 is given on pages $1-50$.

\section{PROJECTS FOR THE SEASON OF 1927}

The projects for the field season of 1927 have been under way only a short time at the end of the fiscal year, and all the parties are out $y$ of touch with any ordinary means of communication, so that it is not possible to make a detailed statement at this time of the work actually accomplished during that fiscal year or the precise cost of that work. The following table, however, sets down in summary form the areas in which the work is being done, the amounts allotted to the field work, and an estimate of the amount for salaries that will be required for the surveys and for the necessary office work in completing for publication the maps and reports that will be prepared as an outcome of that work. In estimating the amount of the salaries it has been assumed that the work will be completed by $\checkmark$ the first of May, so that the field personnel will be available to start on the 1928 field projects by that time; otherwise approximately $\$ 3,700$ additional for technical salaries will be required. 
Approximate cost and distribution of work by geographic divisions for the field season 1927

\begin{tabular}{|c|c|c|c|c|c|}
\hline \multirow{2}{*}{ Region or work } & \multicolumn{2}{|c|}{ 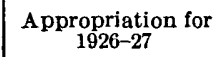 } & \multicolumn{2}{|c|}{$\begin{array}{l}\text { Appropriation for } \\
1927-28\end{array}$} & \multirow{2}{*}{ Total } \\
\hline & Expenses & Salaries & Expenses & Salaries & \\
\hline $\begin{array}{l}\text { Copper River } \\
\text { Alaska Peninsula } \\
\text { Yukon } \\
\text { Airplane-map compilation. } \\
\text { General } \\
\text { Mineral resources............ }\end{array}$ & $\begin{array}{r}\$ 575 \\
1,800 \\
4,250 \\
190\end{array}$ & $\begin{array}{r}\$ 575 \\
1,45 \\
2,510\end{array}$ & $\begin{array}{r}\$ 1,925 \\
6,200 \\
2,750 \\
6,800 \\
810\end{array}$ & \begin{tabular}{r}
$\$ 3,070$ \\
8,170 \\
6,420 \\
\hdashline 1,575 \\
1,950
\end{tabular} & $\begin{array}{r}\$ 6,145 \\
17,615 \\
15,930 \\
6,800 \\
2,575 \\
1,950\end{array}$ \\
\hline & 6,815 & 4,530 & 18,485 & 21,185 & 51,015 \\
\hline
\end{tabular}

- Includes $\$ 1,500$ for clerical services.

The projected work in the Copper River region has been planned to gather data regarding the geology of part of the Nizina and Chitina Valley. Only a small party in charge of F. H. Moffit, with one camp hand, has been assigned to this work. This survey is necessary to correlate certain of the investigations that have been made in the region in earlier years as well as to supplement those more general observations by studying certain areas in more detail and by visiting new areas. All these studies are directed toward deciphering the geologic conditions that relate to the formation of the copper ores of the district as well as toward aiding in determining the geologic history of that part of Alaska. In addition to the duties above set forth Mr. Moffit will collect data regarding the general development of the mining industry in the Copper River region and will visit such operating mines as time and other conditions permit, so as to keep informed of the work in progress.

In the Alaska Peninsula the work planned is practically a continuation of the surveys made at the head of Skwentna River in the $F$ season of 1926. A combined geologic and topographic party in charge of S. R. Capps, geologist, with R. H. Sargent, topographer, left in May to carry on this work. The party planned to land on the west. side of Cook Inlet, surveying the route westward to the mountains as they travel. On reaching the mountains connection with the surveys of 1926 will be effected if practicable, and the rest of the season will be spent in covering as much of the unmapped area as time and other conditions permit. This is a region about which practically nothing is known except that there is a broad lowland between the coast of Cook Inlet and the foothills, west of which are $r$. high, rugged mountains, many of which support glaciers. It is believed that mineral deposits similar to those found at other points along the Alaska Range may also occur in these mountains. Part of the lowlands are undoubtedly underlain by coal beds. 
Geologic and topographic surveys to cover parts of the unexplored region north of the Yukon have been approved. These surveys will connect with the earlier surveys made in part of the valley of Chandalar River and will be carried through as much of the country to the north and east as practicable, so as to join with the surveys made in the season of 1926 on Sheenjek River. In order to take advantage of the better traveling conditions that are found before the snow disappears, Gerald FitzGerald, topographer, left in February to go by the usual routes to Fairbanks and thence overland to Fort Yukon, where he procured the necessary supplies for a six-month field season. According to the plans Mr. FitzGerald and the outfit were then to proceed over the snow to a suitable place on the East Fork of Chandalar River and from that point to distribute the supplies in convenient caches for use during the summer. On the opening of navigation J. B. Mertie, jr., geologist, in charge of the party, went by the usual routes down the Yukon and after picking up supplies and equipment at Fort Yukon proceeded up Chandalar River to join Mr. FitzGerald. The region is so little known that it is not possible at this time to forecast what the party will find in it, but presumably parts of the area are mineral bearing.

The task of compiling maps from the airplane pictures taken by the Navy Department has already been mentioned in describing the work of the season of 1926 . Work on this project has been kept continuously under way, and an additional allotment has been made from the appropriation for 1927-28 to cover the cost of preparing the photographs and taking from the pictures the essential data so that they may be properly incorporated in the maps that are being prepared. As the topographic branch of the Geological Survey has ) a corps of specialists for the preparation of data of this sort, an arrangement has been made whereby they will do that work and turn over the data in such shape that the Alaskan branch will only have to incorporate the data thus received in the maps that it will prepare for publication. No field work is contemplated under this assignment, though it is hoped that more airplane photography may be arranged for in the near future.

1 The only work of a general character for which an allotment had been made and that was to be done in the field season of 1927 is a general survey of the mineral industry, especially in the southwestern , part of Alaska. This work was assigned to Philip S. Smith, who left Washington June 26 to study certain of the mining camps in Seward Peninsula and along the southwestern part of Yukon River.

The canvass of the mineral industry, as already explained, is con' ducted annually, and although the work continues throughout the 
year it has been reported as a seasonal project of the year to which the statistics relate. Thus, as already noted, the statistics for the production of mineral resources in the calendar year of 1926 were included in the projects for 1926, and the similar canvass of the 1927 production is treated solely as a 1927 project. Although some work is done throughout the year, the bulk of the work comes during the later part of the year and in the early part of the succeeding year, so that all the expense of the 1927 canvass is shown as borne by the 1927-28 appropriation. As heretofore, about $\$ 1,500$ for clerical services in preparing these reports is included in this item.

\section{ADMINISTRATIVE SALARIES}

The item for administrative salaries does not include provision for the amount that might properly be charged to administration by the subordinate units of the organization. Thus the administrative duties of the several chiefs of party in relation to the units in their charge or the time of any of the technical or clerical employees required in looking after the work of any assistants in their immediate charge, as, for instance, a topographer looking after the work of a recorder or a clerk having a clerical assistant, are not included in this item. In other words, it is intended to cover in this item only those salaries that are related to the administration of the branch as a whole. The amount expended for administration is unusually low, because owing to the shortage of funds it has been necessary to eliminate as much administration as possible and use the customary administrative officers on field projects. Thus Philip S. Smith, the chief Alaskan geologist, was with a field party from February to October, 1926, and during his absence his duties were performed successively by S. R. Capps until the middle of May, when he left for the field; then by F. H. Moffit until the middle of August, when he left for the field; and then by L. M. Graves, chief clerk, who served as the acting chief until the early part of October. While this practice unquestionably reduced the amount spent for administration, it does not at all follow that this sort of administration is economical. In fact there is good reason to believe that such practice leads to lack of continuity of policy, deferred action, and uncertainty that offset, if not reverse, the apparent saving. With as well organized a machine as the Alaskan branch, which has a personnel familiar with the work through long experience, such a lack of real, administration may not at once seriously impair efficiency, but as a policy it is fundamentally unsound and economically unwise.

\section{OTHER TECHNICAL SALARIES}

The item for other technical services includes all payments made for salaries of the permanent technical force of geologists and en- 
gineers. It covers all time spent on various projects exclusive of administrative duties. In certain of the foregoing tables the amounts paid for salaries in the different projects have been indicated, but that information may be summarized briefly. Appropriate parts of the salaries of the following technical members who were engaged in projects during the season of 1926 were charged to this item; Philip S. Smith, S. R. Capps, F. H. Moffit, J. B. Mertie, jr., geologists: R. H. Sargent, Gerald FitzGerald, K. W. Trimble, and J. O. Kilmartin, topographic engineers; total salary roll, $\$ 19,630$. The technical members who have undertaken projects during the season of 1927, the appropriate parts of whose salaries have been paid from the appropriation for 1926-27, are S. R. Capps, F. H. Moffit, and J. B. Mertie, jr., geologists; and R. H. Sargent and Gerald FitzGerald, topographers. The portions of these men's salaries charged to this item for the season of 1927 up to the end of June 30, 1927, amounted to $\$ 4,530$. The total sum paid from the appropriation for 1926-27 for technical salaries for the two seasons was $\$ 24,160$. In addition to this amount salaries to the extent of about $\$ 6,080$ had been paid from the appropriation for 1925-26 for the beginning of the projects that were continued in the season of 1926, and approximately $\$ 19,685$ has been estimated as the amount that will be required from the appropriation for 1927-28 to complete the projects already under way in the season of 1927 , noted above.

There has been a material reduction in the technical personnel employed during the season of 1927, owing to the small amount of funds available, which has made it necessary to dispense with all but two topographers. Even a further reduction in field activities would have been required had not a furlough of five months been granted to one of the topographers. The curtailment resulted in setting free some funds, but was probably a greater loss to the Government than the total saving, because important work had to be laid aside or handled less efficiently by others who were not so conversant with the details, all of which took more time and gave less sure results. Furthermore, the necessity for all the highest-grade men doing many I minor jobs, because of the virtual elimination of assistants of lower grades and salaries, slowed up the work and doubtless made the unit cost higher.

CLERICAL AND DRAFTING SALARIES

All the clerical and drafting work is performed by one chief clerk, one assistant clerk, and one draftsman. As already noted, part of the time of the chief clerk, Miss L. M. Graves, was spent in branch administration. About three-fourths of the time of the assistant $6097^{\circ}-29-5$ 
clerk is devoted to the preparation of the statistical inquiries relating to the annual mineral production of the Territory and tabulating and computing the results from the replies to these inquiries. For the period up to March, 1927, the statistical work was done by Miss Erma C. Nichols, who has handled the task for several years. Owing to ill health, Miss Nichols was compelled to resign, and temporary assistance in carrying on this work as well as other clerical duties was given by Miss Margaret $\mathrm{H}$. Arrington and later Miss Eleanor W. McKeige. The clerical personnel is entirely too small to handle the large volume of work, so that only the most pressing matters can be attended to, and many jobs that might better and cheaper be done by a clerk must now be done by the technical members rather than incur the otherwise inevitable delay.

\section{MISCELLANEOUS EXPENSES}

The miscellaneous expenses for the operation of the branch are comparatively small. These expenses do not include any iterns directly required in connection with the field projects, such as equipment and supplies, as these are charged directly against the specific project for which they are bought. The principal item under this head relates to work done in making photographs and copies, most of which are required in the compilation of the maps that are in preparation. The cost of work of this type paid for from the appropriation for $1926-27$ was about $\$ 1,100$. This amount is somewhat greater than usual because during that year several large maps were in process of compilation. Other items that go to make up this expense are books, field stationery, repairs to technical equipment, telegrams, and the purchase of any supplies not used directly in a specific field project.

\section{LEASING WORK}

As already noted, the leasing work in Alaska in 1926-27 was conducted from an allotment of $\$ 19,500$ made from a separate item in the appropriation for the Geological Survey. In order that the policies and practices that have been developed for handling the much larger volume of similar work in the States should be main- I! tained so far as they are applicable or appropriately modified to meet Alaskan conditions and in order to utilize the existing agency that is conversant with Alaskan affairs, the general administration, of the leasing work in Alaska rests jointly with the conservation branch and the Alaskan branch. For the conduct of the field work an office is maintained at Anchorage, Alaska, in charge of B. D. Stewart, supervising mining engineer, with a staff of two other engineers, J. J. Corey and J. G. Shepard, together with the necessary 
clerical assistance. During 1926-27 the following was the approximate distribution of funds expended by this office:

Administrative salaries.

Other technical salaries.

Clerical salaries

1,500

Field and office expenses

2,500

19,500

Much of the time of the administrative officer in Alaska is given to field work and other duties not regarded as strictly administrative in character, so that only a proportional part of the salary is charged as a direct administrative expense and the rest is included in the item "Other technical salaries." In addition to the regular staff whose salaries are included in the technical salaries, N. L. Wimmler, H. H. Townsend, and F. W. Holzheimer were employed on different field assignments for varying periods during the season.

The principal leasing activities during the year centered around the coal-mining operations along the line of the Alaska Railroad in the Matanuska and Healy River fields. Here the work of the Federal engineers served not only to take care of the Government's direct interest in its various leases but also to assist the operators with sound technical advice, which enabled them to solve some of their problems and was thus of indirect benefit to the Government and the mining industry. Investigations were also made during the year in the Porcupine region, Hyder district, and part of the Ketchikan region of southeastern Alaska; in the Teikel region, north of Valdez; in the Port Wells district and other parts of the country adjacent to Prince William Sound; in the Kenai district; in the vicinity of Fairbanks; at many places in the Kuskokwim Valley; and in most of the mining districts of Seward Peninsula.

In addition to the principal assigned work of this group of engineers, their familiarity with mining matters throughout many parts of the Territory and their availability for consultation enabled Mr. Stewart and his staff to give much valuable information and advice to many of the Federal and Territorial agencies in Alaska as well I as to many individuals, including the Alaska Railroad, the Forest Service, the governor, members of the Territorial legislature, and many operators and prospectors. The Alaska office also acts as a local distributing office for handling publications of the Geological Survey and assists in furnishing the main office with information on many phases of the mineral industry.

The Alaska office was one of the activities transferred to the Geological Survey from the Bureau of Mines when that bureau was taken over into the Department of Commerce at the beginning of the last fiscal year. One of the reasons for that change was that 
economies of operation might be effected. It has not yet been practicable to put into effect many of the changes that would produce closer coordination between the two types of work carried on by the Alaskan branch, because both appropriations have been materially reduced, so that the work could not be maintained even on its former scale. It is planned, however, that when funds are available fuller utilization of this office in the regular mineral-resources work of the Alaskan branch will be made and that it will participate in many of the activities now carried on under the other appropriation.

For the field season of 1927 , the beginning of which is financed from 1926-27 funds and the later part from 1927-28 funds, there will be some further curtailment, as only $\$ 14,500$ has been allotted for this work from the 1927-28 appropriation. This amount will be barely sufficient to pay the salaries of the permanent force engaged in leasing work with a small allowance for the maintenance of the office and the necessary traveling expenses. The present plans therefore contemplate the continuance of only the most pressing of the investigations and will doubtless necessitate even further reduction of personnel if the essential duties are to be performed. Under these conditions no broad, systematic scheme of investigation can be planned in advance, but instead only a few of the specific jobs as they arise can be given attention. 